\title{
Strontium Isotope Fractionation of Planktic Foraminifera and Inorganic
} Calcite

Florian Böhm, Anton Eisenhauer, Jianwu Tang, Martin Dietzel, Andre Krabbenhöft, Basak Kisakürek, Christian Horn

\author{
Preprint
}

Geochimica Cosmochimica Acta

doi: 10.1016/j.gca.2012.04.038

in press

April, 16, 2012 


\title{
Strontium isotope fractionation of planktic foraminifera and inorganic calcite
}

Florian Böhm ${ }^{1}$, Anton Eisenhauer ${ }^{1}$, Jianwu Tang ${ }^{2}$, Martin Dietzel ${ }^{3}$, Andre Krabbenhöft ${ }^{1}$, Basak Kisakürek ${ }^{1}$, Christian Horn ${ }^{1}$

1: IFM-GEOMAR, Leibniz Institute for Marine Sciences, Kiel, Germany

2: Department of Earth \& Environmental Sciences, Tulane University, New Orleans, USA

3: Institute of Applied Geosciences, Graz University of Technology, Graz, Austria

\begin{abstract}
We have investigated the strontium isotope fractionation $\left(\Delta^{88 / 86} \mathrm{Sr}_{\text {carb-aq }}\right)$ between inorganic calcite and aqueous $\mathrm{Sr}^{2+}$ ions by precipitation experiments at a constant temperature of $25^{\circ} \mathrm{C}$ and precipitation rates (R) ranging from $10^{2.3}$ to $10^{4.2} \mu \mathrm{mol} / \mathrm{m}^{2} / \mathrm{h}$. Strontium isotope ratios were measured using the ${ }^{87} \mathrm{Sr}^{84} \mathrm{Sr}$ double spike technique. It was found that strontium isotope fractionation in these calcites is strongly dependent on the precipitation rate:
\end{abstract}

$$
\Delta^{88 / 86} \mathrm{Sr}_{\text {carb-aq }}=-0.08 * \log \left(\mathrm{R}\left[\mu \mathrm{mol} / \mathrm{m}^{2} / \mathrm{h}\right]\right)+0.08
$$

The measured $\delta^{88 / 86} \mathrm{Sr}$ values are significantly correlated with previously measured $\delta^{44 / 40} \mathrm{Ca}$ and $\mathrm{Sr} / \mathrm{Ca}$ values of the same calcite samples:

$$
\begin{aligned}
& \Delta^{88 / 86} \mathrm{Sr}_{\text {carb-aq }}=+0.18 * \Delta^{44 / 40} \mathrm{Ca}_{\text {carb-aq }}-0.01 \\
& \Delta^{88 / 86} \mathrm{Sr}_{\text {carb-aq }}=-1.5 * \mathrm{~K}_{\mathrm{d}}^{\mathrm{Sr}}-0.03
\end{aligned}
$$

The slope of ${ }^{88} \mathrm{Sr} /{ }^{86} \mathrm{Sr}$ versus ${ }^{44} \mathrm{Ca} /{ }^{40} \mathrm{Ca}$ fractionation is $0.18 \pm 0.04$ and compatible with a kinetic fractionation during dehydration of the strontium and calcium ions, but not with isotope fractionation in a diffusive boundary layer. Using published equilibrium $\Delta^{44 / 40} \mathrm{Ca}_{\text {carb-aq }}$ and $\mathrm{K}_{d}^{\mathrm{Sr}}$ values we estimate the equilibrium isotope fractionation of strontium to be very close to zero $\left(\Delta^{88 / 86} \mathrm{Sr}_{\text {eq(carb- }}\right.$ aq) $=-0.01 \pm 0.06 \%$ ). This estimate is confirmed by strontium isotope values of natural inorganic calcites that precipitated very slowly in basalts of the ocean crust.

The results from the inorganic calcites are used to explain strontium isotope fractionation of planktic foraminifera. Specimens of two warm water species (Globigerinoides ruber and Globigerinoides sacculifer) were picked from the Holocene section of a Caribbean sediment core. We found no significant difference in $8^{88 / 86} \mathrm{Sr}$ between the two species. In addition, G. ruber specimens from Marine Isotope Stage 2 in the same core show $\delta^{88 / 86} \mathrm{Sr}$ values identical to the Holocene specimens. 
The strontium isotopes of both foraminifera species are strongly fractionated $\left(\Delta^{88 / 86} \mathrm{Sr}_{\text {carb-aq }}=-0.248\right.$ $\pm 0.005 \%$ ) when compared to published data of other major marine calcifiers. Applying the results from the inorganic precipitation experiments we find that the strong foraminiferal strontium isotope fractionation can be explained by calcification in a largely open system at high precipitation rates, comparable in magnitude to rates known from scleractinian reef corals. This interpretation is in good agreement with the kinetic calcification model for planktic foraminifera by Kisakürek et al. (GCA 75 (2011), 427), which was based on calcium isotopes and elemental $\mathrm{Sr} / \mathrm{Ca}$ ratios.

Keywords: inorganic calcite, planktic foraminifera, stable strontium isotopes, calcium isotopes, precipitation rate, diffusive boundary layer, isotope fractionation.

\section{INTRODUCTION}

Planktic foraminifera are among the most important calcium carbonate $\left(\mathrm{CaCO}_{3}\right)$ producers in the modern oceans, responsible for about $20 \%$ of the global $\mathrm{CaCO}_{3}$ accumulation flux. Thus, they play an important role in the marine calcium cycle (Milliman and Droxler, 1996; Schiebel, 2002). Strontium and calcium cycling are closely coupled in the marine environment. With an average strontium concentration of about $1300 \mu \mathrm{g} / \mathrm{g}$ (Carpenter and Lohman, 1992) planktic foraminiferal calcite also represents an important strontium sink, responsible for about 5-10\% of the marine strontium burial flux (Krabbenhöft et al., 2010).

Recent compilations of the marine strontium isotope budget show that several major $\mathrm{CaCO}_{3}$ producers (reef corals, Halimeda, coccoliths, molluscs) have $\Delta^{88 / 86} \mathrm{Sr}_{\text {carb-aq }}$ values between -0.2 and $-0.1 \%$, while planktic foraminifera have a significantly lower $\Delta^{88 / 86} \mathrm{Sr}_{\text {carb-aq }}$ value of about $-0.25 \%$ or even less (Krabbenhöft et al., 2010; Liebetrau et al., 2009; Stevenson et al., 2010; $\Delta^{88 / 86} \mathrm{Sr}_{\text {carb-aq }}=$ $\left.\left.\delta^{88 / 86} \mathrm{Sr}_{\text {sample }}-\delta^{88 / 86} \mathrm{Sr}_{\text {fluid }}, \delta^{88 / 86} \mathrm{Sr}=\left[\left({ }^{88} \mathrm{Sr} /{ }^{86} \mathrm{Sr}\right)_{\text {sample }} /\left({ }^{88} \mathrm{Sr} /{ }^{86} \mathrm{Sr}\right)\right)_{\text {standard }}-1\right] * 1000\right)$. Therefore shells of planktic foraminifera may constitute a significant sink of isotopically light strontium in the global strontium cycle.

Little is known about fractionation mechanisms of strontium isotopes during mineral formation. The recent developments in the precision of strontium isotope fractionation analysis (Fietzke and Eisenhauer, 2006; Ohno and Hirata, 2007; Krabbenhöft et al., 2009) have provided data for the first overviews of the strontium isotope systematics in marine biogenic carbonates and for continental weathering (Halicz et al., 2008; Rüggeberg et al., 2008; de Souza et al., 2010; Krabbenhöft et al., 
2010). However, systematic investigations of strontium isotope fractionation during mineral formation are still very rare (Fietzke and Eisenhauer, 2006; Halicz et al., 2008).

On the other hand, investigations of calcium isotopes in experimentally precipitated and diagenetically altered calcite have provided evidence for very strong precipitation rate effects on isotope fractionation (Lemarchand et al., 2004; Fantle and DePaolo, 2007; Tang et al., 2008b). In order to find out whether similar kinetic effects also control strontium isotope fractionation, we investigated inorganic calcite samples that were precipitated in experiments with a given range of distinct precipitation rates at constant temperature. The same samples were previously studied for elemental strontium partitioning and calcium isotope fractionation (Tang et al., $2008 \mathrm{a}, \mathrm{b}$ ). Results from these two studies showed an inverse linear correlation between strontium partitioning $\left(\mathrm{K}_{\mathrm{d}}^{\mathrm{Sr}}=\right.$ $\left.(\mathrm{Sr} / \mathrm{Ca})_{\text {calcite }} /(\mathrm{Sr} / \mathrm{Ca})_{\text {fluid }}\right)$ and calcium isotope fractionation $\left(\Delta^{44 / 40} \mathrm{Ca}_{\text {carb-aq }}=\delta^{44 / 40} \mathrm{Ca}_{\text {calcite }}-\delta^{44 / 40} \mathrm{Ca}_{\text {fluid }}\right)$, which are both mainly controlled by precipitation rate. Based on these results, planktic foraminifera data were interpreted by Kisakürek et al. (2011) to indicate calcification at high rates in a semi-open system, with less than half of the available calcium being utilized for calcite precipitation.

In this study, we measured the strontium isotopic composition $\left(\delta^{88 / 86} \mathrm{Sr}\right)$ of inorganic calcite and of two species of planktic foraminifera, Globigerinoides ruber and Globigerinoides sacculifer, to test two hypotheses: 1. whether strontium isotope fractionation in calcite depends on precipitation rate, and 2. whether the relatively strong strontium isotope fractionation of planktic foraminiferal calcite is caused by high calcification rates.

\section{MATERIAL AND METHODS}

\subsection{Foraminifera}

Piston core SO 164-03-4 was collected from 2745 mbsl (meters below sea level) at the Beata Ridge in the Central Caribbean $\left(16^{\circ} 32.37^{\prime} \mathrm{N}, 72^{\circ} 12.31^{\prime} \mathrm{W}\right)$ during the Sonne cruise SO164 in May 2002. Planktic foraminifera of the species Globigerinoides sacculifer and Globigerinoides ruber were picked from soft sediments in the upper $1.2 \mathrm{~m}$ of the core, consisting of sandy clay (Nürnberg et al., 2003). The sampled Holocene interval, 10-43 cm, corresponds to an age from about 1 to $7 \mathrm{ka}$ (based on unpublished oxygen isotope data measured on benthic foraminifera, Cibicidoides wuellerstorfi, by Joachim Schönfeld, IFM-GEOMAR, Kiel). In addition we measured G. ruber specimens from about $1 \mathrm{~m}$ depth, corresponding to Marine Isotope Stage 2 (last glacial maximum), about 22-25 ka. The glacial specimens formed at a lower temperature than the Holocene specimens and were used to check for a possible temperature dependence of foraminiferal strontium isotope fractionation. For 
each strontium isotope analysis 50 to 80 specimens were picked from the 315 - $355 \mu \mathrm{m}$ size fraction, corresponding to a sample weight of about $1 \mathrm{mg}$. Sediment samples were freeze dried, washed and sieved $(>63 \mu \mathrm{m})$ before picking. The foraminifera were crushed, ultrasonically treated for $30 \mathrm{~s}$ and washed with water several times. Subsequently they were washed twice with methanol and rinsed with water, in order to remove any remaining clay particles. The washed samples were treated with a $\mathrm{NaOH}$ buffered $\mathrm{H}_{2} \mathrm{O}_{2}$ solution and heated to about $95^{\circ} \mathrm{C}$ for 20 minutes. Finally, the samples were washed twice with water, dried, and dissolved in doubly distilled ca. $1.5 \mathrm{~N} \mathrm{HNO}_{3}$. The solutions were evaporated under infrared light and redissolved in $200 \mu \mathrm{l}$ of $8 \mathrm{~N} \mathrm{HNO}_{3}$.

\subsection{Inorganic calcite}

Inorganic calcite samples were available from a previous study of strontium incorporation and calcium isotope fractionation described in Tang et al. (2008 a, b). In these experiments calcite was precipitated spontaneously using an advanced $\mathrm{CO}_{2}$-diffusion technique adapted from Dietzel and Usdowski (1996) and Dietzel et al. (2004). This technique allows to simultaneously control precipitation rate and temperature.

Briefly, various precipitation rates were adjusted by the $\mathrm{CO}_{2}$ flux through a polyethylene membrane at a constant temperature of $25^{\circ} \mathrm{C}$. $\mathrm{SrCl}_{2} \cdot 6 \mathrm{H}_{2} \mathrm{O}$ (Merck pro analysi) was added to $5 \mathrm{~L}$ of a $\mathrm{CaCl}_{2}$ $\mathrm{NH}_{4} \mathrm{Cl}$ solution $\left(10 \mathrm{mM} \mathrm{CaCl}_{2}, 5 \mathrm{mM} \mathrm{NH}_{4} \mathrm{Cl}\right)$ with an ionic strength of about $0.035 \mathrm{M}$. The molar $\mathrm{Sr} / \mathrm{Ca}$ ratio in solution was about 0.01 . Less than $2 \%$ of the strontium in solution was precipitated during the experiments. The $\mathrm{pH}$ was kept constant during precipitation at $8.3 \mathrm{by} \mathrm{pH}$-stat titration with a $\mathrm{NaOH}$ solution. Precipitation rates were calculated from the total amount of calcite precipitated, the time period of calcite growth, and the average crystal surface area for each experimental run (Tang et al., 2008a).

Six samples from these experiments were selected for strontium isotope analyses (Table 1) to cover the whole available range of precipitation rates. From each of the 6 experiments between 1 and 7 mg of calcite were dissolved in ca. $1.5 \mathrm{~N} \mathrm{HNO}_{3}$, dried down and redissolved in $8 \mathrm{~N} \mathrm{HNO}_{3}$.

\subsection{Natural calcite cements}

Two samples of inorganic calcite precipitated in veins during low temperature alteration of ocean crust basalt were picked from cores drilled during DSDP Leg 37 (Mid-Atlantic Ridge, $37^{\circ} \mathrm{N}$, water depth $3188 \mathrm{~m}$ ). Two samples were collected from centimetre-sized veins, using a hand-held microdrill. Several mg of calcite powders were collected for each sample, dissolved in ca. $1.5 \mathrm{~N}$ 
$\mathrm{HNO}_{3}$, dried down and redissolved in $8 \mathrm{~N} \mathrm{HNO}_{3}$.

The basalts at this site formed during geomagnetic polarity chron C5r (11 to $12 \mathrm{Ma}$, Miles and Howe, 1977; Gradstein et al., 2004). The calcites precipitated slightly later, at about $7 \mathrm{Ma}$, as evident from the radiogenic ${ }^{87} \mathrm{Sr} /{ }^{86}$ ratios of the samples (Table 2). Oxygen isotope values of the two samples indicate formation in deep water at temperatures of about $2^{\circ} \mathrm{C}$. Due to the limited supply of carbonate ions in the cold deep water, these calcite cements presumably grew with very slow precipitation rates and show quasi-equilibrium values for calcium isotopes (Böhm et al., 2009). Using the rate dependence of $\mathrm{K}_{d}^{\text {Sr }}$ from Tang et al (2008a) and measured Sr/Ca ratios of the calcite samples (Table 2) we can roughly estimate the precipitation rate of the vein calcites to be in the order of $10 \mu \mathrm{mol} / \mathrm{m}^{2} / \mathrm{h}$. This value is calculated adopting the modern seawater $\mathrm{Sr} / \mathrm{Ca}$ of 8.6 $\mathrm{mmol} / \mathrm{mol}$ in North Atlantic deep waters (deVilliers, 1999). If seawater $\mathrm{Sr} / \mathrm{Ca}$ at $7 \mathrm{Ma}$ was lower than in the modern oceans (about $7 \mathrm{mmol} / \mathrm{mol}$, Coggon et al., 2010) then precipitation rates would have been slightly higher, corresponding to about $30 \mu \mathrm{mol} / \mathrm{m}^{2} / \mathrm{h}$. In both cases calcium isotopes would be close to equilibrium $\left(\Delta^{44 / 40} \mathrm{Ca}_{\text {carb-aq }}\right.$ of approximately $-0.3 \%$ or $-0.4 \%$, respectively, Tang et al., 2008b).

\subsection{Strontium isotope analysis}

Strontium isotope fractionation $\left(\delta^{88 / 86} \mathrm{Sr}\right)$ as well as radiogenic strontium $\left({ }^{87} \mathrm{Sr} /{ }^{86} \mathrm{Sr}\right)$ were measured on aliquots of each sample, following the procedure described in Krabbenhöft et al. (2009). Measurements were carried out at the IFM-GEOMAR mass spectrometer facilities in Kiel, Germany, with a Finnigan (ThermoFisher) Triton TI (Thermal Ionization Mass Spectrometer, TIMS). Samples containing 560 to $2400 \mathrm{ng}$ of strontium were split into two aliquots. One aliquot was spiked with a ${ }^{87} \mathrm{Sr} /{ }^{84} \mathrm{Sr}$ double spike to measure $\delta^{88 / 86} \mathrm{Sr}$, with about $95 \%$ of ${ }^{84} \mathrm{Sr}$ contributed by the spike to the total ${ }^{84} \mathrm{Sr}$ in the spike-sample mixture (Krabbenhöft et al., 2009). Strontium of spiked and unspiked sample aliquots was extracted from the sample matrix with a chromatographic column setup, using 200 to $300 \mu 1$ of Eichrom SrSpec resin for samples with 280 to $1200 \mathrm{ng}$ strontium. Samples were loaded and washed with $8 \mathrm{~N} \mathrm{HNO}_{3}$. Strontium was eluted with $6 \mathrm{ml}$ ultrapure $\mathrm{H}_{2} \mathrm{O}\left(18.2 \mathrm{M} \Omega * \mathrm{~cm}\right.$ at $\left.25^{\circ} \mathrm{C}\right)$. After separation samples were dried down in teflon beakers and boiled at $120^{\circ} \mathrm{C}$ for several hours with a $1: 1$ mixture of $\mathrm{HNO}_{3}(65 \%)$ and $\mathrm{H}_{2} \mathrm{O}_{2}(30 \%)$ to remove residual resin. Finally samples were dried again and 140 to $600 \mathrm{ng}$ of strontium were loaded with $\mathrm{H}_{3} \mathrm{PO}_{4}$ and $\mathrm{TaCl}_{5}$ activator onto Re filaments. No column chemistry was carried out for preparation of the standard (NIST SRM 987) and for the $\mathrm{SrCl}_{2}$ used in the calcite precipitation setups. 
Measurements were made with single filaments at a temperature of about $1350-1400^{\circ} \mathrm{C}$ and a typical ${ }^{88} \mathrm{Sr}$ signal intensity of about $50 \mathrm{pA}$ corresponding to a voltage of $5 \mathrm{~V}$. Signals of masses 84 to 88 were recorded simultaneously. Mass 85 was used to correct for ${ }^{87} \mathrm{Rb}$ interferences, assuming a natural ${ }^{87} \mathrm{Rb} /{ }^{85} \mathrm{Rb}$ ratio of 0.3857 .

Spike correction and normalization of the results was carried out as described in Krabbenhöft et al. (2009). Radiogenic ${ }^{87} \mathrm{Sr} /{ }^{86} \mathrm{Sr}$ ratios were determined by normalizing the spike corrected ${ }^{87} \mathrm{Sr} /{ }^{86} \mathrm{Sr}^{*}$ ratios (for definition see Appendix A in Krabbenhöft et al., 2010) to the recommended ${ }^{86} \mathrm{Sr} /{ }^{88} \mathrm{Sr}$ ratio of 0.1194 (Nier, 1938, Steiger and Jäger, 1977). The standard NIST SRM987 was measured with an average ${ }^{87} \mathrm{Sr} /{ }^{86} \mathrm{Sr}$ value of $0.710233(8)(1 \mathrm{sd}, \mathrm{n}=12)$. Radiogenic ${ }^{87} \mathrm{Sr} /{ }^{86} \mathrm{Sr}$ ratios of all natural samples were adjusted to ${ }^{87} \mathrm{Sr} /{ }^{86} \mathrm{Sr}_{\mathrm{SRM} 987}$ of 0.710248 for comparison with values of the "Strontium Isotope Stratigraphy" of McArthur and Howarth (2004).

The ${ }^{88} \mathrm{Sr} /{ }^{86} \mathrm{Sr}$ ratios are reported in the common delta notation relative to NIST SRM987: $\delta^{88 / 86} \mathrm{Sr}=$ $\left.\left[{ }^{88} \mathrm{Sr} /{ }^{86} \mathrm{Sr}\right)_{\text {sample }} /\left({ }^{88} \mathrm{Sr} /{ }^{86} \mathrm{Sr}\right)_{\mathrm{SRM} 987}-1\right] * 1000$ using the ${ }^{88} \mathrm{Sr} /{ }^{86} \mathrm{Sr}$ ratio of SRM987 standards measured during the same session as the samples. The isotope fractionation is given as $\Delta^{88 / 86} \mathrm{Sr}_{\text {carb-aq }}=$ $\delta^{88 / 86} \mathrm{Sr}_{\text {calcite }}-\delta^{88 / 86} \mathrm{Sr}_{\text {fluid. }}$ Errors are based on repeated analyses of samples and standards and are given as 2SEM (standard error of the mean), unless noted otherwise. The average ${ }^{88} \mathrm{Sr} /{ }^{86} \mathrm{Sr}$ ratio of SRM987 was determined as $8.37515(14)$. The long-term analytical precision for $\delta^{88 / 86} \mathrm{Sr}$ was determined from repeated measurements of SRM987 as $\pm 0.01 \%$ ( $(1 \mathrm{sd}, \mathrm{n}=12)$.

Two batches of $\mathrm{SrCl}_{2}$ were used in the calcite precipitation experiments, showing different ${ }^{87} \mathrm{Sr} /{ }^{86} \mathrm{Sr}$ ratios $[0.70784(2)$ and $0.70869(1)]$ but similar $\delta^{88 / 86} \mathrm{Sr}$ values $(0.158 \pm 0.006 \%, \mathrm{n}=7$, and $0.154 \pm 0.009 \%, \mathrm{n}=5)$. We therefore pooled all measured $\delta^{88 / 86} \mathrm{Sr}$ values of the two batches, resulting in an average $\delta^{88 / 86} \mathrm{Sr}$ of $0.156 \pm 0.005 \%$ o $(2 \mathrm{SEM}, \mathrm{n}=12$ ). This value was adopted for the strontium isotopic composition of the fluids used in all precipitation experiments.

With only up to $2 \%$ of the dissolved strontium used in the experiments, the influence of Rayleigh fractionation effects is insignificant $(<0.002 \%$ for bulk calcite samples). Up to $15 \%$ of the calcium in solution was taken up by the precipitated calcite introducing a small systematic bias of up to $0.09 \%$ to the $\Delta^{44 / 40} \mathrm{Ca}_{\text {carb-aq }}$ values. Calcium isotope values were therefore Rayleigh fractionation corrected based on data from Tang et al. (2008b) (Table 1). The strontium distribution coefficients $\left(\mathrm{K}_{d}^{\mathrm{Sr}}\right)$ listed in Table 1 were corrected for Rayleigh distillation effects by Tang et al. (2008a).

\section{RESULTS}

The results of the strontium isotope analyses are shown in Tables 1, 2, and 3 . The average 
radiogenic ${ }^{87} \mathrm{Sr} /{ }^{86} \mathrm{Sr}$ ratios of Holocene G. ruber, glacial G. ruber, and Holocene G. sacculifer are 0.709176(5), 0.709173(4) and 0.709167(10), respectively. The values are indistinguishable within error $\left(\mathrm{p}=0.25\right.$, t-test). They are identical within statistical uncertainty to the average ${ }^{87} \mathrm{Sr} /{ }^{86} \mathrm{Sr}$ ratio of modern seawater calculated from three recent publications (0.709175(8), McArthur et al., 2006, Fantle and DePaolo, 2006, Krabbenhöft et al., 2009, $\mathrm{p}_{\text {ruber }}=0.80, \mathrm{p}_{\text {sacculifer }}=0.34$, t-test) indicating the preservation of a pristine seawater signal in the sampled foraminiferal calcite.

The average $\Delta^{88 / 86} \mathrm{Sr}_{\text {carb-aq }}$ values of Holocene G. ruber $(-0.25 \pm 0.01 \%)$, glacial G. ruber $(-0.25 \pm$ $0.01 \%$ ), and Holocene G. sacculifer $\left(-0.25 \pm 0.01 \%\right.$ ) are indistinguishable within error ( $\mathrm{p}_{\text {ruber-sacculifer }}$ $=0.81, \mathrm{p}_{\text {Holocene-glacial }}=0.30$, t-test). There is no significant temperature influence on the $\Delta^{88 / 86} \mathrm{Sr}_{\text {carb-aq }}$ values in the Holocene-glacial G. ruber data $\left(\mathrm{R}^{2}=0.28, \mathrm{p}=0.27\right.$, linear regression).

Strontium isotope fractionation $\left(\Delta^{88 / 86} \mathrm{Sr}_{\text {carb-aq }}\right)$ during the experimental calcite formation is significantly influenced by precipitation rate (Fig. 1). The resulting regression equation (with 95\% confidence intervals) is:

$\Delta^{88 / 86} \mathrm{Sr}_{\text {carb-aq }}[\% \mathrm{o}]=(-0.084 \pm 0.044) * \log \left(\mathrm{R}\left[\mu \mathrm{mol} / \mathrm{m}^{2} / \mathrm{h}\right]\right)+0.08 \pm 0.15 ;\left(\mathrm{R}^{2}=0.87, \mathrm{p}=0.003\right)$

Comparison with the strontium distribution coefficient $\left(\mathrm{K}_{d}^{\mathrm{Sr}}\right)$ measured on aliquots of the analyzed samples shows a significant negative correlation between $\Delta^{88 / 86} \mathrm{Sr}_{\text {carb-aq }}$ and $\mathrm{K}_{d}{ }^{\mathrm{Sr}}$ (Fig. 2):

$\Delta^{88 / 86} \mathrm{Sr}_{\text {carb-aq }}[\% \mathrm{o}]=(-1.50 \pm 0.7) * \mathrm{~K}_{\mathrm{d}}^{\mathrm{Sr}}-0.03 \pm 0.09 ;\left(\mathrm{R}^{2}=0.89, \mathrm{p}=0.002\right)$

Assuming that the equilibrium $\mathrm{K}_{d}{ }^{\mathrm{Sr}}$ of calcite is close to zero (Tesoriero and Pankow, 1996, Tang et al. 2008a) we can use y-axis intercept of the regression equation (Eq. 2) to estimate the equilibrium fractionation of strontium isotopes for calcite to be $\Delta^{88 / 86} \mathrm{Sr}_{\mathrm{eq}(\mathrm{carb}-\mathrm{aq})}=-0.03 \pm 0.09 \%$. The two analyzed natural calcite samples show $\Delta^{88 / 86} \mathrm{Sr}_{\text {carb-aq }}$ values in this range (Fig. 2).

Calcium isotope fractionation was previously measured on aliquots of the analyzed samples (Tang et al., 2008b). A regression between strontium isotopes and calcium isotopes shows a highly significant positive correlation (Fig. 3):

$\Delta^{88 / 86} \mathrm{Sr}_{\text {carb-aq }}[\%$ o $]=(0.176 \pm 0.04) * \Delta^{44 / 40} \mathrm{Ca}_{\text {carb-aq }}[\%$ o $]-0.01 \pm 0.05 ;\left(\mathrm{R}^{2}=0.97, \mathrm{p}=0.0001\right)$

The natural calcites fit very well on this regression (Fig. 3). Again we can estimate $\Delta^{88 / 86} \mathrm{Sr}_{\text {eq(carb-aq) }}$ from the regression intercept, assuming $\Delta^{44 / 40} \mathrm{Ca}_{\text {eq(carb-aq) }}=0.0 \%$ o (Fantle and DePaolo, 2007): 
$\Delta^{88 / 86} \mathrm{Sr}_{\text {eq(carb-aq) }}=-0.01 \pm 0.05 \%$. Both estimates, based on $\mathrm{K}_{\mathrm{d}}^{\mathrm{Sr}}$ and $\Delta^{44 / 40} \mathrm{Ca}_{\text {carb-aq }}$, agree within uncertainties and show an equilibrium strontium isotope fractionation $\left(\Delta^{88 / 86} \mathrm{Sr}_{\text {eq(carb-aq }}\right)$ very close to zero.

\section{DISCUSSION}

\subsection{Inorganic calcite}

Our results show a significant rate dependence for strontium isotope fractionation in calcite. We observe increasing discrimination of heavy strontium isotopes with increasing precipitation rates (Fig. 1). In this regard strontium isotopes behave like calcium isotopes, which also show a negative correlation between precipitation rate and isotope fractionation (Tang et al., 2008b). The precipitation rate effect on calcium isotopes has been explained by two alternative models, both based on the interplay of kinetic and equilibrium isotope fractionations.

In the "surface entrapment model" (Watson, 2004; Tang et al., 2008a, b) kinetic fractionation leads to a preferential incorporation of light isotopes at the crystal surface. Subsequently, isotopic equilibrium is slowly approached through ion diffusion in the near surface region of the growing crystal. The isotopic equilibration of the former surface layer is eventually stopped when it is trapped under further crystal layers and diffusional ion exchange with the fluid is halted. The higher the precipitation rate the shorter is the time available for isotopic equilibration.

In the "surface reaction kinetic model" (DePaolo, 2011) kinetic fractionation during precipitation again leads to an enrichment of light isotopes in the crystal surface layer. Isotopic equilibration is approached by ion exchange between fluid and crystal surface, i.e. by precipitation/dissolution (forward/backward) reactions. Eqilibration is halted when due to continued growth the crystal layer is no longer in contact with the fluid.

In both models the isotopic composition of the crystal reflects equilibrium fractionation at slow precipitation rates and kinetic fractionation when crystal growth is fast. Both models can explain the interdependencies of rate and temperature controls of calcium isotopes as well as the $\mathrm{Sr} / \mathrm{Ca}$ ratios observed in calcite (Tang et al., 2008a, b). By analogy with the calcium isotopes the two models can also be used to explain the rate dependence of strontium isotopes in the inorganic calcite samples. Two major factors control the isotopic rate effect of cation incorporation in a growing crystal: (1) the isotopic difference between the kinetically fractionated surface layer and the equilibrium composition; (2) the rate of isotopic equilibration of the crystal surface layer. The latter depends on 
the cation diffusivity in the near surface layer of the crystal (surface entrapment model) or on the ratio between net precipitation rate and dissolution rate (surface reaction kinetic model). From this point of view comparing the rate dependencies of calcium and strontium isotopes may provide clues to the fractionation mechanism that leads to the isotopic enrichment of the surface layer. It is well known that calcite crystals preferentially take up light calcium isotopes, with fractionation $\left(\Delta^{44 / 40} \mathrm{Ca}_{\text {carb-aq }}\right)$ commonly between -0.5 and $-1.0 \%$, approaching $-1.5 \%$ in some cases (e.g. Marriott et al., 2004; Lemarchand et al., 2004; DePaolo, 2004; Gussone et al., 2003, 2005, 2007). Equivalent preferential uptake of light strontium isotopes has been observed in several studies of calcite and aragonite (Fietzke and Eisenhauer, 2006; Ohno and Hirata, 2007; Halicz et al., 2008; Rüggeberg et al., 2008; Krabbenhöft et al., 2010; Knudson et al., 2010) and is also evident from the results of this study (Fig. 2).

On the other hand, it has been shown that the calcium isotopic compositions of calcite and ambient pore fluids are very similar $\left(\Delta^{44 / 40} \mathrm{Ca}_{\mathrm{eq}(\mathrm{carb}-\mathrm{aq})} \approx 0.0 \%\right.$ o $)$ in systems where sufficient time is available for isotopic equilibration (Fantle and DePaolo, 2007; Jacobson and Holmden, 2008; Böhm et al., 2009). This seems to be the case for strontium isotopes too $\left(\Delta^{88 / 86} \mathrm{Sr}_{\text {eq(carb-aq })} \approx 0.0 \%\right.$, Fig. 1$)$. Therefore, in accord with the two rate models described above, the discrimination of heavy calcium and strontium isotopes during crystal formation is most likely a process occurring at the surface of the crystal under non-equilibrium conditions. It is caused by kinetic isotope fractionation $\left({ }^{44 / 40} \mathrm{Ca}_{\text {kin(carb- }}\right.$ aq) $<-1.5 \%$; $\Delta^{88 / 86} \mathrm{Sr}_{\text {kin(carb-aq) }}<-0.3 \%$ o). Equilibrium fractionation of calcite does not partition isotopes of either element $\left(\Delta^{44 / 40} \mathrm{Ca}_{\text {eq(carb-aq) }} \approx 0 \% ; \Delta^{88 / 86} \mathrm{Sr}_{\text {eq(carb-aq) }} \approx 0 \%\right.$ ). Consequently, the observed correlation of the rate dependent calcium and strontium isotope fractionations and the slope of the resulting regression line (Eq. 3, Fig. 3) should primarily reflect the ratio ( $\beta$ ) of the respective $\Delta_{\text {kin(carb- }}$ aq) values of the two elements:

$$
\Delta^{88 / 86} \mathrm{Sr}_{\text {kin(carb-aq) }}=\beta * \Delta^{44 / 40} \mathrm{Ca}_{\text {kin(carb-aq) }} \text { or } \beta=\Delta^{88 / 86} \mathrm{Sr}_{\text {kin(carb-aq) }} / \Delta^{44 / 40} \mathrm{Ca}_{\text {kin(carb-aq) }}
$$

Eq. (4) can be interpreted to reflect the different masses of strontium and calcium with the assumption that the two elements differ in their reduced partition function ratios and reaction rate constant ratios only due to their different masses. This approach is certainly a crude approximation but, with the similar chemical behaviour of the two elements, may nevertheless provide some information about the possible frationation mechanisms that lead to the observed linear correlation of $\Delta^{88 / 86} \mathrm{Sr}_{\text {carb-aq }}$ and $\Delta^{44 / 40} \mathrm{Ca}_{\text {carb-aq }}$.

Eq. (4) can be derived from Eq. (5), the general equation for the mass dependence of isotope 
fractionation (Young et al., 2002)

$$
{ }^{88 / 86} \alpha_{\text {kin(carb-aq) }}={ }^{44 / 40} \alpha_{\text {kin(carb-aq) }}{ }^{\beta} \text { or } \ln \left({ }^{88 / 86} \alpha_{\text {kin(carb-aq) }}\right)=\beta * \ln \left({ }^{44 / 40} \alpha_{\text {kin(carb-aq) }}\right)
$$

by recasting with $\Delta_{\text {carb-aq }} \approx 1000 \ln \left(\alpha_{\text {carb-aq }}\right)$. The exponent $\beta$ in Eq. (5) is a function of the respective isotope masses and the fractionation mechanism (Young et al., 2002)

$$
\begin{aligned}
& \beta_{\text {eq }}=\left(87.906^{-1}-85.909^{-1}\right) /\left(43.955^{-1}-39.963^{-1}\right)=0.12 \\
& \beta_{\text {kin }}=\log \left(\mu_{\mathrm{Sr}(\mathrm{h})} / \mu_{\mathrm{Sr}(\mathrm{l})}\right) / \log \left(\mu_{\mathrm{Ca}(\mathrm{h})} / \mu_{\mathrm{Ca}(\mathrm{l})}\right) \\
& \beta_{\text {diff }}=\log (87.906 / 85.909) / \log (43.955 / 39.963)=0.24
\end{aligned}
$$

for equilibrium, chemical kinetic, and diffusional kinetic fractionation mechanisms, respectively. The masses in Eqs. (6) and (7b) are the atomic masses of the strontium and calcium isotopes of interest. Masses in Eq. (7a), $\mu_{\mathrm{i}(\mathrm{h})}$ and $\mu_{\mathrm{i}(\mathrm{l})}$, represent reduced masses for the heavy and light isotopes of element $\mathrm{i}$, respectively, where $\mu_{\mathrm{i}}=\mathrm{M} * \mathrm{~m}_{\mathrm{i}} /\left(\mathrm{M}+\mathrm{m}_{\mathrm{i}}\right)$. Symbol $\mathrm{m}_{\mathrm{i}}$ denotes the atomic isotope mass of interest, $\mathrm{M}$ is the mass of the molecules contributing to the reacting complex bonded to the element of interest (Young et al., 2002).

The resultant value for equilibrium fractionation (Eq. 6) is $\beta_{\mathrm{eq}}=0.12$, calculated with the atomic masses of calcium and strontium. This is significantly lower than the measured value of $0.18 \pm 0.04$ (Eq. 3). However, the observed value is close to $\beta_{\text {kin }}=0.19 \pm 0.04$ for chemical kinetic isotope fractionation during dehydration of $\mathrm{Sr}^{2+}$ and $\mathrm{Ca}^{2+}$ aquocomplexes, having 6 to 8 water molecules in the inner hydration sphere (Megyes et al., 2004; Seward et al., 1999; Tofteberg et al., 2006). The latter range of $\beta_{\text {kin }}$ values is calculated with Eq. (7) by adopting the reduced masses of the aquocomplexes calculated with $\mathrm{M}=108.1 \mathrm{amu}$ for $\left(\mathrm{H}_{2} \mathrm{O}\right)_{6}, \mathrm{M}=144.1 \mathrm{amu}$ for $\left(\mathrm{H}_{2} \mathrm{O}\right)_{8}$ and the respective atomic strontium and calcium isotope masses.

Alternatively, kinetic fractionation during aqueous cation diffusion through a diffusive boundary layer (see Section 4.2) may explain the observed slope $\beta$. It was recently suggested that the atomic masses determine the fractionation of ions diffusing in water. The fractionation factor is further controlled by the residence time $\left(\tau_{\mathrm{s}}\right)$ of water molecules in the inner solvation shell of the diffusing cation-aquocomplexes (Bourg et al., 2010). Assuming that $\mathrm{Sr}^{2+}$ and $\mathrm{Ca}^{2+}$ have similar $\tau_{\mathrm{s}}$ (Kerisit and Parker, 2004) we can calculate $\beta_{\text {diff }}=0.24$ with Eq. (7b). This value is significantly higher than the observed $\beta$ of $0.18 \pm 0.04$. In addition, as will be shown in the next section, the isotope fractionation effects of cation diffusion in water are much too small to explain the observed isotope fractionation 
of calcium and probably also of strontium.

We therefore suggest that chemical kinetic isotope fractionation (Bigeleisen, 1949) involving dehydration of $\mathrm{Sr}^{2+}$ and $\mathrm{Ca}^{2+}$ ions could be the primary mechanism responsible for the enrichment of light calcium and strontium isotopes in calcite crystals. $\mathrm{Sr}^{2+}$ and $\mathrm{Ca}^{2+}$ ions in aqueous solution obviously have to be dehydrated before they can be incorporated into the calcite crystal lattice (e.g. Raiteri et al., 2010; Marriott et al., 2004). This process can cause a kinetic isotope fractionation with a preferential dehydration of the lighter isotopes, which then could be more readily incorporated in the crystal lattice (DePaolo, 2011). This kinetic isotope partitioning can be temperature dependent, with decreasing partitioning at higher temperatures, because it involves the breaking of bonds (Bigeleisen, 1949). This temperature dependence of the dehydration induced kinetic isotope fractionation could explain the similar temperature control on the calcium isotopic composition of aragonite, calcite, and possibly calcium passing through biological membranes, which was observed in several previous studies (Gussone et al., 2003, 2005, 2006; Marriott et al., 2004; Böhm et al., 2006; Griffith et al., 2008b; Tang et al., 2008b).

As shown above the $\Delta^{88 / 86} \mathrm{Sr}_{\text {kin(carb-aq) }} / \Delta^{44 / 40} \mathrm{Ca}_{\text {kin(carb-aq) }}$ ratio observed in our data (Fig. 3, Eq. 3) can be explained by mass-dependent isotope fractionation. However, it is likely that differences in the chemical behaviour of the two elements additionally influence and modify the $\Delta^{88 / 86} \mathrm{Sr}_{\text {kin(carb- }}$ aq) $/ \Delta^{44 / 40} \mathrm{Ca}_{\text {kin(carb-aq) }}$ ratio. Nevertheless, the agreement between the observed slope $(0.18 \pm 0.04)$ and the $\Delta^{88 / 86} \mathrm{Sr}_{\text {kin(carb-aq) }} / \Delta^{44 / 40} \mathrm{Ca}_{\text {kin(carb-aq) }}$ ratio expected for mass-dependent kinetic isotope fractionation $(0.19 \pm 0.04)$ is in line with chemical kinetic isotope fractionation being the dominant mechanism responsible for the observed correlated rate effects.

Chemical kinetic isotope fractionation has previously been proposed to play a dominant role for the partitioning of magnesium and calcium isotopes during calcite precipitation (e.g. Gussone et al., 2003; DePaolo, 2011; Wombacher et al., 2011). Our results indicate that the same fractionation process may also control strontium isotope incorporation into calcite.

\subsection{Diffusive boundary layer}

It has been suggested that significant calcium and strontium isotope fractionation may occur in the diffusive boundary layer that forms around growing crystals and living organisms (Fantle and DePaolo, 2007; Watson and Müller, 2009). Diffusive boundary layers (DBL) form due to the depletion of the fluid in elements or isotopes that are preferentially taken up by the crystal or 
organism. This selective uptake leads to the formation of gradients between the surface of the particle and the bulk solution (Zeebe and Wolf-Gladrow, 2001). Gradients in the concentrations of $\mathrm{O}_{2}, \mathrm{CO}_{2}, \mathrm{CO}_{3}^{2-}, \mathrm{H}^{+}$and $\mathrm{Ca}^{2+}$ have been observed in water around living symbiotic foraminifera (e.g. Köhler-Rink and Kühl, 2005; de Beer et al., 2008) and at the surface of corals (Al-Horani et al., 2003). The maximum thickness of these boundary layers is determined by micro eddies in turbulent water (about $1 \mathrm{~mm}$ in ocean water), or is in the same order of magnitude as the particle radius (Zeebe and Wolf-Gladrow, 2001). In stirred solutions like in our experimental setup the boundary layer thickness can as small as $20 \mu \mathrm{m}$ (DePaolo, 2011). Köhler-Rink and Kühl (2005) observed a decrease in $\left[\mathrm{Ca}^{2+}\right]$ of about $5 \%$ between bulk solution and the surface of a shell of a calcifying planktic foraminifer. They calculated a diffusional transit time for $\mathrm{Ca}^{2+}$ ions through a $0.4 \mathrm{~mm}$ thick layer of about 4 minutes. Based on these observations it is plausible that calcium or strontium isotopes are fractionated in a diffusive boundary layer, however, the magnitude of this fractionation is not clear.

In solutions with very high $\left[\mathrm{Ca}^{2+}\right] /\left[\mathrm{CO}_{3}{ }^{2-}\right]$ ratio, like in seawater or in our experiments, the limited supply of $\mathrm{CO}_{3}{ }^{2-}$ ions for precipitation of calcite prevents the development of a strong diffusional $\left[\mathrm{Ca}^{2+}\right]$ gradient (DePaolo, 2011; see Appendix). On the other hand, Fantle and DePaolo (2007) suggested that the enrichment of heavy calcium isotopes in a diffusive boundary layer around fast growing calcite crystals could explain results of Lemarchand et al. (2004). The latter observed an increase in $\delta^{44 / 40} \mathrm{Ca}$ of calcite with increasing precipitation rate, opposite to the later observations of Tang et al. (2008b). Originally, Lemarchand et al. (2004) had explained this observation by the entrapment of an increasing percentage of unfractionated dissolved $\mathrm{Ca}^{2+}$ at very fast crystal growth rates. Much lower $\delta^{44 / 40} \mathrm{Ca}$ values at low growth rates were explained by partial isotopic equilibration between fluid and crystal. Lemarchand et al. (2004) consequently estimated the equilibrium ${ }^{44} \mathrm{Ca} /{ }^{40} \mathrm{Ca}$ fractionation of calcite $\left(\Delta^{44 / 40} \mathrm{Ca}\right.$ eq(arb-aq) $)$ as on the order of $-1.5 \%$. In a study of the isotopic composition of pore fluids in Neogene calcite oozes from the Ontong Java Plateau Fantle and DePaolo (2007) showed that calcium isotope equilibrium fractionation should in fact lead to high $\delta^{4 / 40} \mathrm{Ca}$ values, thereby disproving the model of Lemarchand et al. (2004). Additional evidence for the boundary layer model of Fantle and DePaolo (2007) was provided by the strongly reduced isotope fractionation in experiments by Lemarchand et al. (2004) where the growth solution was stirred, while much stronger fractionation effects were found in unstirred experiments. Neither Lemarchand et al. (2004) nor Fantle and DePaolo (2007) attempted to quantify the fractionation processes in the diffusive boundary layer. New experimental and theoretical results (Bourg et al., 2010; Watson and Müller, 2009) have recently provided the basis for a quantification 
of such processes. We therefore developed a set of equations based on the diffusion model of Watson and Müller (2009) and the measurements of diffusive calcium isotope fractionation in water (Bourg et al., 2010) to quantify the isotope fractionation in diffusive boundary layers. We use a simplified 1-dimensional steady state approach (Watson and Müller, 2009). This approach provides an upper limit for possible isotope fractionation effects, because the latter are maximized for 1dimensional diffusion and for steady state (i. e. for a constant concentration gradient in the diffusive boundary layer).

To calculate isotope fractionation effects in the diffusive boundary layer we use three equations describing the composition of the DBL at the liquid-crystal boundary (see Appendix for derivation of the equations). The solute concentrations of the major calcite constitutents, $\mathrm{Ca}^{2+}$ and $\mathrm{CO}_{3}{ }^{2-}$, are described by Eq. (8):

$$
\mathrm{C}_{\mathrm{L}}=\left(\mathrm{C}_{0} * \mathrm{D}-\mathrm{V} * \mathrm{BT} * \mathrm{C}_{\mathrm{X}}\right) /(\mathrm{D}-\mathrm{V} * \mathrm{BT})
$$

$\mathrm{C}_{\mathrm{L}}\left(\mathrm{C}_{\mathrm{L}}^{\mathrm{Ca}}, \mathrm{C}_{\mathrm{L}}^{\mathrm{CO} 3}\right)$ is the ion concentration at the liquid-crystal boundary $\left(\mathrm{mmol} / \mathrm{cm}^{3}\right) . \mathrm{V}$ is the crystal extension rate $(\mathrm{cm} / \mathrm{s})$, which is related to precipitation rate, $\mathrm{R}$, by $\mathrm{V}=\mathrm{R} * \mathrm{M}_{\mathrm{cc}} / \rho_{\mathrm{cc}}$, with the molecular weight $\left(\mathrm{M}_{\mathrm{cc}}=100.0869 \mathrm{~g} / \mathrm{mol}\right)$ and the density $\left(\rho_{\mathrm{cc}}=2.71 \mathrm{~g} / \mathrm{cm}^{3}\right)$ of calcite. BT is the boundary layer thickness $(\mathrm{cm})$. $\mathrm{D}$ is the diffusion coefficient $\left(\mathrm{D}_{\mathrm{Ca}}=7 * 10^{-6} \mathrm{~cm}^{2} / \mathrm{s}\right.$, Boudreau, 1997 , $\mathrm{D}_{\mathrm{CO} 3}=8^{*} 10^{-6} \mathrm{~cm}^{2} / \mathrm{s}$, Wolf-Gladrow and Riebesell, 1997). $\mathrm{C}_{\mathrm{x}}$ and $\mathrm{C}_{0}$ are the concentrations in the calcite crystal and in the bulk fluid, respectively $\left(\mathrm{C}^{\mathrm{Ca}}{ }_{\mathrm{x}}=\mathrm{C}^{\mathrm{CO} 3}{ }_{\mathrm{x}}=27.1 \mathrm{mmol} / \mathrm{cm}^{3}, \mathrm{C}^{\mathrm{Ca}}=10.3\right.$ $\mu \mathrm{mol} / \mathrm{cm}^{3}, \mathrm{C}^{\mathrm{CO} 3}{ }_{0}=0.26 \mu \mathrm{mol} / \mathrm{cm}^{3}$; with $\mathrm{C}^{\mathrm{CO} 3}{ }_{0}$ for warm ocean surface waters).

The latter numbers show that concentrations increase by several orders of magnitude between bulk fluid and calcite crystal. Therefore high precipitation rates can only be maintained if very thin boundary layers allow a sufficiently fast diffusive transport of the rate limiting ions, i.e. of $\mathrm{CO}_{3}{ }^{2-}$ in seawater-like solutions. The maximum rates in our experiments $\left(10^{4.2} \mu \mathrm{mol} / \mathrm{m}^{2} / \mathrm{h}\right)$ can only be maintained with a boundary layer thickness of less than about 0.05-0.1 mm (see Appendix, Table A2).

The difference in the calcium isotopic composition between bulk fluid and the fluid at the liquidcrystal interface is given by:

$\Delta^{44 / 40} \mathrm{Ca}_{\mathrm{DBL}}=\left(\mathrm{C}^{\mathrm{Ca}} * \alpha^{44}{ }_{\mathrm{d}} * \mathrm{D}_{\mathrm{Ca}} /\left(\mathrm{V} * \mathrm{BT} *\left(\alpha^{44}{ }_{\mathrm{x}} * \mathrm{C}_{\mathrm{X}}^{\mathrm{Ca}}-\mathrm{C}_{\mathrm{L}}^{\mathrm{Ca}}\right)+\alpha^{44}{ }_{\mathrm{d}} * \mathrm{D}_{\mathrm{Ca}} * \mathrm{C}_{\mathrm{L}}^{\mathrm{Ca}}\right)-1\right) * 1000$

$\mathrm{C}^{\mathrm{Ca}}{ }_{\mathrm{L}}$ is calculated with Equ. (8). There are two different isotope fractionation processes that modify 
the composition of the diffusive boundary layer. One is reflected in the fractionation factor $\alpha^{44}$ which describes the ${ }^{44} \mathrm{Ca} /{ }^{40} \mathrm{Ca}$ fractionation during diffusive transport of calcium in water, $\mathrm{D}^{44}{ }_{\mathrm{Ca}} / \mathrm{D}^{40}{ }_{\mathrm{Ca}}$. Bourg et al. (2010) determined $\alpha^{44}{ }_{\mathrm{d}}=0.99957$. The faster diffusive transport of light calcium leads to an enrichment of light isotopes in the boundary layer compared to the bulk fluid. The second mechanism changing the isotopic composition in the DBL is the preferential uptake of light calcium by the calcite crystal, reflected in $\alpha^{44}{ }_{\mathrm{x}}$. For room temperature $\alpha^{44}{ }_{\mathrm{x}}$ was estimated to be about 0.9985 (-1.5\%) by Lemarchand et al. (2004), in general agreement with the DePaolo (2011) model results (-1.6 to $-1.7 \%$ ) and with our experimental results (-1.6\%o, see Fig. 3). A lower value for $\alpha^{44}{ }_{x}(0.9980,-2.0 \%$ ) was reported by Reynard et al. (2011). We use 0.9985 in Eq. (9) which results in a maximum $\Delta^{44 / 40} \mathrm{Ca}$ DBL of $1.07 \%$ with the unrealistic assumption that calcium can be completely depleted at the liquid-crystal boundary, or more realistically, $0.05 \%$ if calcium depletion is limited by carbonate ion availability as discussed above (Figure 4; see also Appendix). With the lower $\alpha^{44}{ }_{\mathrm{x}}$ value of Reynard et al. (2011) the maximum $\Delta^{44 / 40} \mathrm{Ca}_{\mathrm{DBL}}$ would increase to 1.57 or $0.07 \%$, respectively. In any case, the heavy isotope enrichment effect of $\alpha^{44}{ }_{x}$ dominates over the diffusive depletion, $\alpha^{44}$. Therefore $\Delta^{44 / 40} \mathrm{Ca}_{\mathrm{DBL}}$ is always positive. It increases with increasing crystal growth rate (Fig. 4) and with increasing boundary layer thickness (Table A1). This can be different for DBLs in media where $\alpha^{44}$ is smaller than $\alpha^{44}$, e.g. in hot silicate melts (Richter et al. 2003). In general $\Delta^{44 / 40} \mathrm{Ca} \mathrm{DBL}_{\mathrm{DB}}$ is a linear function of the relative depletion of calcium in the $\mathrm{DBL}, \mathrm{C}_{\mathrm{L}}^{\mathrm{Ca}} / \mathrm{C}^{\mathrm{Ca}}{ }_{0}$ (Fig. 5). At higher $\mathrm{C}^{\mathrm{Ca}}{ }_{0}$ the relative depletion $\mathrm{C}^{\mathrm{Ca}}{ }_{\mathrm{L}}$ is less strong for given $\mathrm{V}$ and $\mathrm{BT}$ values.

Therefore the magnitude of $\Delta^{44 / 40} \mathrm{Ca}_{\mathrm{DBL}}$ decreases with increasing bulk calcium concentration $\mathrm{C}^{\mathrm{Ca}}{ }_{0}$ (Fig. 4).

The DBL effect on strontium isotopes is quantified by

$$
\begin{aligned}
\Delta^{88 / 86} \mathrm{Sr}_{\mathrm{DBL}}= & \left(\left(\mathrm{V} * \mathrm{BT} * \alpha_{{ }_{\mathrm{d}}}^{88} *\left(\mathrm{~K}_{\mathrm{d}}^{\mathrm{Sr}} * \mathrm{C}_{\mathrm{X}}^{\mathrm{Ca}}-\mathrm{C}_{\mathrm{L}}^{\mathrm{Ca}}\right)+\alpha_{\mathrm{d}}^{88} * \mathrm{D}_{\mathrm{Sr}} * \mathrm{C}_{\mathrm{L}}^{\mathrm{Ca}}\right) /\right. \\
& \left.\left(\mathrm{V} * \mathrm{BT} *\left(\alpha^{88} * \mathrm{~K}_{\mathrm{d}}{ }^{\mathrm{Sr}} * \mathrm{C}_{\mathrm{X}}^{\mathrm{Ca}}-\mathrm{C}_{\mathrm{L}}^{\mathrm{Ca}}\right)+\alpha^{88}{ }_{\mathrm{d}} * \mathrm{D}_{\mathrm{Sr}} * \mathrm{C}_{\mathrm{L}}^{\mathrm{Ca}}\right)-1\right) * 1000
\end{aligned}
$$

$\mathrm{K}_{d}^{\mathrm{Sr}}$ is the distribution coefficient of strontium between fluid and calcite. We use $\mathrm{K}_{d}^{\mathrm{Sr}}=0.11$, the average from Table $1 . \mathrm{D}_{\mathrm{Sr}}$, the diffusion coefficient for $\mathrm{Sr}^{2+}$ in water, is very similar to that of $\mathrm{Ca}^{2+}$ (Li and Gregory, 1974). We therefore use the same coefficient for calcium and strontium. Assuming that isotope fractionation during diffusion of $\mathrm{Sr}^{2+}$ and $\mathrm{Ca}^{2+}$ depends primarily on the different isotope masses, as discussed in the previous section, we estimate $\alpha_{\mathrm{d}}^{88}=\mathrm{D}_{88 \mathrm{Sr}} / \mathrm{D}_{86 \mathrm{Sr}}$ to be 0.99990 ($0.1 \%$ ), analogous to $\mathrm{D}_{44 \mathrm{Ca}} / \mathrm{D}_{40 \mathrm{Ca}}$. For $\alpha^{88}{ }_{\mathrm{x}}$ we use a value of $0.9997(-0.3 \%$ ), which corresponds to the lowest $\Delta^{88 / 86} \mathrm{Sr}_{\text {carb-aq }}$ value observed in our experiments (Fig. 3). 
The uptake of strontium into calcite changes with the fluid $\mathrm{Sr} / \mathrm{Ca}$ ratio, controlled by $\mathrm{K}_{d}^{\mathrm{Sr}}$. Therefore $\Delta^{88 / 86} \mathrm{Sr}_{\mathrm{DBL}}$ is independent of the bulk fluid strontium concentration, $\mathrm{C}^{\mathrm{Sr}}{ }_{0}$, but rather depends on $\mathrm{C}^{\mathrm{Ca}}{ }_{0}$ and $\mathrm{C}_{\mathrm{L}}^{\mathrm{Ca}}$ (see Appendix, Table A1). With the weaker isotope fractionation of strontium the increase of $\Delta^{88 / 86} \mathrm{Sr}_{\mathrm{DBL}}$ with crystal growth rate is much smaller than for calcium, but there is still always an enrichment in heavy isotopes in the DBL (Fig. 4). The maximum isotope fractionation constrained by available calcium is $0.2 \%$ (Fig. 5). With the carbonate chemistry limitations the maximum $\Delta^{88 / 86} \mathrm{Sr}_{\mathrm{DBL}}$ value is $0.001 \%$. Contrary to the DBL isotope fractionation effect for $\mathrm{Ca}, \Delta^{88 / 86} \mathrm{Sr}_{\mathrm{DBL}}$ shows a non-linear relationship to the element depletion in the $\mathrm{DBL}\left(\mathrm{C}^{\mathrm{Sr}} / \mathrm{C}^{\mathrm{Sr}}{ }_{0}\right.$ and $\left.\mathrm{C}_{\mathrm{L}}^{\mathrm{Ca}} / \mathrm{C}^{\mathrm{Ca}}{ }_{0}\right)$. Therefore $\Delta^{88 / 86} \mathrm{Sr}_{\mathrm{DBL}}$ and $\Delta^{44 / 40} \mathrm{Ca}_{\mathrm{DBL}}$ are not linearly correlated (Fig. 5).

The magnitude of isotope fractionation due to diffusional transport is much too small (Fig. 4) to explain the increasing depletion of heavy isotopes with increasing preciptation rate observed by Tang et al. (2008b) and in this study (Fig. 1). Rather, the preferred uptake of light isotopes into calcite enriches the fluid near the crystal in heavy isotopes. In fluids with low $\left[\mathrm{Ca}^{2+}\right] /\left[\mathrm{CO}_{3}{ }^{2-}\right]$ ratios and high precipitation rates this process may lead to a significant fractionation effect with increasing heavy isotope enrichment at increasing precipitation rates. However, the DBL mechanism can not explain the positive $\Delta^{44 / 40} \mathrm{Ca}_{\text {carb-aq }}$-rate relationship observed by Lemarchand et al. (2004) because $\Delta^{44 / 40} \mathrm{Ca}_{\mathrm{DBL}}$ differs significantly for experiments with different $\left[\mathrm{Ca}^{2+}\right]$ concentrations. Lemarchand et al. (2004) observed no isotopic difference between experiments with $\left[\mathrm{Ca}^{2+}\right]$ concentrations that differed by a factor of 10. As shown in Fig. 4 this concentration difference would have resulted in 10 times smaller $\Delta^{44 / 40} \mathrm{Ca}_{\mathrm{DBL}}$ values for the high concentrations. In well stirred experiments using fluids with seawater-like $\left[\mathrm{Ca}^{2+}\right] /\left[\mathrm{CO}_{3}{ }^{2-}\right]$ ratios DBL effects are negligible for strontium and calcium isotopes (Fig. 4). We therefore conclude that diffusive boundary layer effects can not explain any of the rate dependencies of calcium and strontium isotope fractionation observed by Lemarchand et al. (2004), Tang et al. (2008b), and in this study.

\subsection{Planktic foraminifera}

$\mathrm{Mg} / \mathrm{Ca}$ ratios of G. ruber specimens from the same core samples as used in this study inidcate a $\sim 4^{\circ} \mathrm{C}$ temperature increase from the last glacial to the Holocene (Table 3 ). Two studies have previously observed a temperature dependence of strontium isotope fractionation in inorganic and biogenic aragonite (Fietzke and Eisenhauer, 2006; Rüggeberg et al., 2008). Applying the temperature sensitivities reported in these papers would result in a $\delta^{88 / 86} \mathrm{Sr}$ difference of 0.02 to $0.13 \%$ between the glacial and Holocene G. ruber samples. The observed difference 
$(0.007 \pm 0.014 \%$; Table 3$)$ does not indicate a temperature sensitivity of this magnitude for G. ruber. The measured mean foraminiferal $\Delta^{88 / 86} \mathrm{Sr}_{\text {carb-aq }}$ value of $-0.25 \%$ is significantly lower than most published values of marine biogenic carbonates where $\Delta^{88 / 86} \mathrm{Sr}_{\text {carb-aq }}$ ranges from $-0.20 \%$ to $-0.12 \%$ o (Krabbenhöft et al., 2010, Liebetrau et al., 2009; Ohno and Hirata, 2007). This means that planktic foraminifera shells are more strongly fractionated in ${ }^{88} \mathrm{Sr} /{ }^{86} \mathrm{Sr}$ than most other biogenic carbonates. On the other hand, the observed foraminiferal $\Delta^{88 / 86} \mathrm{Sr}_{\text {carb-aq }}$ is in good agreement with the $\Delta^{88 / 86} \mathrm{Sr}_{\text {carb-aq }}$ of inorganic calcite that is formed at high precipitation rate. We therefore suggest that the strong foraminiferal strontium isotope fractionation is caused by high precipitation rates $\left(\mathrm{R}>10^{3.5}\right.$ $\mu \mathrm{mol} / \mathrm{m}^{2} / \mathrm{h}$ ). Kisakürek et al. (2011) suggested similar fast precipitation rates to explain high $\mathrm{Sr} / \mathrm{Ca}$ ratios and low calcium isotope values observed in cultured planktic foraminifera (G. ruber and Globigerinella siphonifera). Their model further suggested that shell formation used less than 50\% of the calcium ions supplied to the calcification site. As we will show below, the foraminiferal strontium isotope fractionation data as well as the elemental $\mathrm{Sr} / \mathrm{Ca}$ ratios and the calcium isotope fractionation are all compatible with calcite growth in a calcification space that is largely open to exchange with seawater, in accordance with the model of Kisakürek et al. (2011).

Our measured foraminiferal $\Delta^{88 / 86} \mathrm{Sr}_{\text {carb-aq }}$ data, combined with published average values for $\mathrm{K}_{d}^{\mathrm{Sr}}$ and $\Delta^{44 / 40} \mathrm{Ca}_{\text {carb-aq }}$, plot close to the respective inorganic calcite regression lines (Fig. 2, 3). For this comparison we use the average $\Delta^{44 / 40} \mathrm{Ca}_{\text {carb-aq }}=-1.14 \pm 0.05 \%$ of $G$. ruber from culture experiments carried out at 27 to $30^{\circ} \mathrm{C}$, pH of 8.3 to $8.4,35$ psu (Kisakürek et al., 2011). For G. sacculifer we use the average $\Delta^{44 / 40} \mathrm{Ca}_{\text {carb-aq }}=-1.10 \pm 0.09 \%$ of culture and sediment trap samples, representing specimens not showing strong temperature effects, and grown at different salinities and $27-28^{\circ} \mathrm{C}$ (Gussone et al., 2009; Griffith et al., 2008b). We further use average $\mathrm{K}_{d}{ }^{\text {Sr }}$ values from a core top transect published by Elderfield et al. (2000). They found $\mathrm{K}_{d}{ }^{\mathrm{Sr}}$ values of 0.167 and 0.163 for $G$. ruber and G. sacculifer, respectively. As shown in Fig. 2, both foraminifera species plot within the $95 \%$-confidence belt of the inorganic calcite regression line. This result indicates that both the strontium concentration and the isotopic composition of G. ruber and G. sacculifer can be explained by inorganic processes dominated by precipitation rate effects.

Consequently, we can use the regression in Fig. 1 to estimate the average precipitation rates of $G$. ruber and G. sacculifer. We find rates higher than $10^{3.5} \mu \mathrm{mol} / \mathrm{m}^{2} / \mathrm{h}$, with a best fit value of $10^{3.9}$ $\mu \mathrm{mol} / \mathrm{m}^{2} / \mathrm{h}$ for both species. Slightly lower precipitation rates of $10^{3.30}$ to $10^{3.48} \mu \mathrm{mol} / \mathrm{m}^{2} / \mathrm{h}$ were measured by Lea et al. (1995) using ${ }^{48} \mathrm{Ca}$ uptake experiments with the planktic foraminiferal species Orbulina universa. Using $\mathrm{K}_{d}^{\text {Sr }}$ to estimate precipitation rates, applying a regression of the data from Tang et al. (2008a), results in higher rates. We find a minimum rate of $10^{4.0} \mu \mathrm{mol} / \mathrm{m}^{2} / \mathrm{h}$ and a best fit 
value of $10^{4.2} \mu \mathrm{mol} / \mathrm{m}^{2} / \mathrm{h}$.

The calcium isotopic composition of the two species shows slightly higher $\Delta^{44 / 40} \mathrm{Ca}_{\text {carb-aq }}$ values than expected from the inorganic calcite data (Fig. 3), plotting just outside the $95 \%$ confidence belt. We assume that both the strontium concentration and the strontium isotopic composition of G. ruber and G. sacculifer are primarily explained by high precipitation rates (Fig. 2). In contrast, the calcium isotopic composition may be affected by an additional, albeit minor, mechanism. As previously suggested, calcium isotopes in these planktic foraminifera are possibly influenced by a Rayleigh distillation effect (Griffith et al., 2008b; see discussion in Kisakürek et al., 2011). Rayleigh distillation can sufficiently explain the observed slight enrichment in $\delta^{44 / 40} \mathrm{Ca}$. From the difference between the measured $\Delta^{44 / 40} \mathrm{Ca}_{\text {carb-aq }}$ of $-1.1 \%$ for G. sacculifer and G. ruber and the expected inorganic value from the $\Delta^{88 / 86} \mathrm{Sr}_{\text {carb-aq }}-\Delta^{44 / 40} \mathrm{Ca}_{\text {carb-aq }}$ regression shown in Fig. 3, we can estimate the percentage of calcium in the calcification reservoir that is consumed during calcification. To do this, we take the $\delta^{4 / 40} \mathrm{Ca}$ enrichment with respect to the $95 \%$ confidence belt of the regression in Fig. 3 and apply a Rayleigh fractionation equation (Zeebe and Wolf-Gladrow, 2001). For the given $\Delta^{88 / 86} \mathrm{Sr}_{\text {carb-aq }}=-0.25 \%$ value of $G$. sacculifer and $G$. ruber we calculate that $20 \%$ to $50 \%$ of the calcium in the reservoir is used to form calcite with the measured apparent $\Delta^{44 / 40} \mathrm{Ca}_{\text {carb-aq. }}$. The most likely value is $30 \%$.

The resulting Rayleigh effect on the apparent $\mathrm{K}_{d}^{\mathrm{Sr}}$ would be an increase by 0.025 . The true $\mathrm{K}_{d}^{\mathrm{Sr}}$ would therefore be slightly lower than the measured value, but would still plot within the $95 \%$ confidence belt of the inorganic calcite line (Fig. 2). The true planktic foraminiferal $\Delta^{44 / 40} \mathrm{Ca}_{\text {carb-aq }}$ value defined by the measured strontium isotope value and the regression line in Fig. 3 would be $-1.3 \%$. This value corresponds to a calcification rate of $10^{3.8} \mu \mathrm{mol} / \mathrm{m}^{2} / \mathrm{h}$ according to Tang et al. (2008b).

For the calculations outlined above we assume that all calcium is derived from a reservoir with seawater isotopic composition. In contrast, Griffith et al. (2008b) and Gussone et al. (2009) proposed models for calcification of planktic foraminifera which assumed a calcification reservoir that was depleted in ${ }^{44} \mathrm{Ca}$ with respect to seawater. Griffith et al. (2008b) further assumed a very efficient use of the calcium reservoir $\left(85 \% \mathrm{Ca}^{2+}\right.$ used, in accord with Elderfield et al., 1996). Gussone et al. (2009) proposed a temperature-dependent utilization of a strongly fractionated internal calcium reservoir with admixture of seawater calcium to explain the strong temperature dependence of calcium isotope fractionation sometimes observed in G. sacculifer.

Our strontium isotope data cannot exclude these models of highly efficient utilisation of $\mathrm{a}^{44} \mathrm{Ca}$ depleted reservoir. Because very little strontium is taken up into foraminiferal calcite the 
corresponding Rayleigh effect on $\Delta^{88 / 86} \mathrm{Sr}_{\text {carb-aq }}$ is very small even if $85 \%$ of the calcium reservoir are used. With a calcification fluid of normal seawater composition $(\mathrm{Sr} / \mathrm{Ca}$ fluid $\mathrm{ca} .10 \mathrm{mmol} / \mathrm{mol})$ and with a $\mathrm{K}_{d}^{\mathrm{Sr}}$ of about 0.16 the percentage of $\mathrm{Sr}^{2+}$ used is $5 \%$ for $30 \% \mathrm{Ca}^{2+}$ utilization and $25 \%$ for $85 \% \mathrm{Ca}^{2+}$ utilization. The resulting Rayleigh effect on the apparent $\delta^{88 / 86} \mathrm{Sr}$ would only be $+0.005 \%$ and $+0.030 \%$, respectively.

Consequently, while strontium isotopes provide a good proxy for the calcification rate of foraminiferal calcite, they do not provide useful constraints to quantify Rayleigh distillation effects. Nevertheless, our model is able to explain strontium incorporation, strontium isotope fractionation as well as calcium isotope fractionation in G. sacculifer and G. ruber calcite by very high precipitation rates (about $10^{3.8} \mu \mathrm{mol} / \mathrm{m}^{2} / \mathrm{h}$ ) from a fluid with seawater composition for both strontium and calcium, and a poor utilization efficiency for calcium $\left(30 \%\right.$ of available $\left.\mathrm{Ca}^{2+}\right)$ and strontium ( $5 \%$ of available $\left.\mathrm{Sr}^{2+}\right)$.

\section{CONCLUSIONS}

Strontium isotope fractionation of inorganic calcite is predominantly controlled by the precipitation rate with increasing fractionation at higher rates and no significant isotope fractionation at very low rates. This kinetic fractionation behaviour is similar for strontium and calcium isotopes, leading to a linear correlation of the two isotope systems in experimental inorganic calcites. The correlation indicates that a similar mechanism controls calcium and strontium isotope fractionation. This mechanism probably involves chemical kinetic fractionation of the hydrated cations (preferred desolvation of the isotopically light cations). In addition, strontium and calcium isotope partitioning are both inversely correlated with the rate dependent partitioning of strontium ions between fluid and calcite. Two different possible mechanisms that can explain this correlated behaviour of elemental and isotopic partitioning have been proposed in the Surface Entrapment Model (Watson, 2004; Tang et al., 2008 a,b) and recently in the Surface Kinetic Model of DePaolo (2011). This correlation can, however, not be explained by partitioning in a diffusive boundary layer around the growing calcite crystals.

The predominance of heavy isotope enrichment in the boundary layer over depletion by diffusional kinetic fractionation would lead to an enrichment of heavy isotopes in the crystal at increasing precipitation rates. The opposite was observed in our experiments for both calcium and strontium isotopes. Additionally, the relative enrichment of strontium with respect to calcium in the diffusive boundary layer would lead to a positive correlation of $\mathrm{Sr} / \mathrm{Ca}$ ratios with both isotope systems. The opposite is observed in our experimental results. On the other hand, our observations do not exclude 
either the Surface Entrapment Model or the Surface Kinetic Model. Both models can well explain the observed trends and correlations of elemental and isotope partitioning.

The exceptionally strong strontium isotope fractionation of planktic foraminifera can be explained by very fast precipitation of their calcitic chambers. Together with calcium isotope and $\mathrm{Sr} / \mathrm{Ca}$ data from the two investigated species (G. ruber, G. sacculifer) the strontium isotope data point to calcification in a system where only a relatively small percentage of the calcium transported to the site of calcification is used for the formation of calcite.

\section{ACKNOWLEGDEMENTS}

This study was supported by the German Science Foundation (DFG), projects Ei272/22, Ei272/23, Ei272/24 (SPP 527, IODP/ODP), and Ei272/30 (TRION). We thank Svenja Rausch and Wolfgang Bach for their help with the ocean crust basalt samples, which were provided by the Deep Sea Drilling Project (DSDP). Many thanks to Ana Kolevica and Hauke Vollstaedt for help with the strontium isotope analyses and to Frank Wombacher and Nikolaus Gussone for discussions of isotope fractionation mechanisms. We thank Alex Gagnon, Edwin Schauble and two anonymous reviewers for very valuable comments.

\section{REFERENCES}

Al-Horani F. A., Al-Moghrabi S. M., de Beer D. (2003) The mechanism of calcification and its relation to photosynthesis and respiration in the scleractinian coral Galaxea fascicularis. Marine Biology 142, 419-426.

Bigeleisen J. (1949) The Relative Reaction Velocities of Isotopic Molecules. Journal of Chemical Physics 17, 675-678.

Böhm F., Gussone N., Eisenhauer A., Dullo W.-C., Reynaud S., Paytan A. (2006) Calcium isotope fractionation in modern scleractinian corals. Geochimica et Cosmochimica Acta 70, 4452-4462.

Böhm F., Eisenhauer A., Rausch S., Bach W., Klügel A. (2009): Calcium isotope systematics of low temperature alteration carbonates in the ocean crust. Abstract 19th V.M. Goldschmidt Conference, Geochim. Cosmochim. Acta 73/13 Suppl.1, A133.

Boudreau B. P. (1997) Diagenetic models and their implementation. 414 pp, Springer, Berlin. 
Bourg I. C., Richter F. M., Christensen J. N., Sposito G. (2010) Isotopic mass dependence of metal cation diffusion coefficients in liquid water. Geochimica et Cosmochimica Acta 74, 2249-2256.

Carpenter S. J., Lohmann K. C. (1992): Sr/Mg ratios of modern marine calcite: Empirical indicators of ocean chemistry and precipitation rate. Geochim. Cosmochim. Acta 56, 1837-1849.

Coggon R. M., Teagle D. A. H., Smith-Duque C. E., Alt J. C., Cooper M. J. (2010) Reconstructing past seawater $\mathrm{Mg} / \mathrm{Ca}$ and $\mathrm{Sr} / \mathrm{Ca}$ from mid-ocean ridge flank calcium carbonate veins. Science 327, 1114-1147.

de Beer D., Bissett A., de Wit R., Jonkers H. (2008) A microsensor for carbonate ions suitable for microprofiling in freshwater and saline environments. Limnology and Oceanography: Methods 6, 532-541.

DePaolo D. J. (2004) Calcium Isotopic Variations Produced by Biological, Kinetic, Radiogenic and Nucleosynthetic Processes. Reviews in Mineralogy and Geochemistry 55, 255-288.

DePaolo D. J. (2011) Surface kinetic model for isotopic and trace element fractionation during precipitation of calcite from aqueous solutions. Geochimica et Cosmochimica Acta 75, 10391056.

de Souza G. F., Reynolds B. C., Kiczka M., Bourdon B. (2010) Evidence for mass-dependent isotopic fractionation of strontium in a glaciated granitic watershed. Geochimica et Cosmochimica Acta 74, 2596-2614.

de Villiers S. (1999) Seawater strontium and $\mathrm{Sr} / \mathrm{Ca}$ variability in the Atlantic and Pacific oceans. Earth and Planetary Science Letters 171, 623-634.

Dietzel M., Usdowski E. (1996) Coprecipitation of $\mathrm{Ni}^{2+}, \mathrm{Co}^{2+}$, and $\mathrm{Mn}^{2+}$ with galena and covellite, and of $\mathrm{Sr}^{2+}$ with calcite during crystallization via diffusion of $\mathrm{H}_{2} \mathrm{~S}$ and $\mathrm{CO}_{2}$ through polyethylene at $20^{\circ} \mathrm{C}$ : Power law and Nernst law control of trace element partitioning. Chemical Geology 131, $55-65$.

Dietzel M., Gussone N., Eisenhauer A. (2004) Co-precipitation of $\mathrm{Sr}^{2+}$ and $\mathrm{Ba}^{2+}$ with aragonite by membrane diffusion of $\mathrm{CO}_{2}$ between 10 and $50^{\circ} \mathrm{C}$. Chemical Geology 203, 139-151.

Elderfield H., Bertram C. J., Erez J. (1996) A biomineralization model for the incorporation of trace elements into foraminiferal calcium carbonate. Earth and Planetary Science Letters 142, 409423.

Elderfield H., Cooper M., Ganssen G. (2000) Sr/Ca in multiple species of planktonic foraminifera: Implications for reconstructions of seawater $\mathrm{Sr} / \mathrm{Ca}$. Geochemistry Geophysics Geosystems $\mathbf{1}$. doi:10.1029/1999GC000031.

Fantle M. S., DePaolo D. J. (2006) Sr isotopes and pore fluid chemistry in carbonate sediment of the Ontong Java Plateau: Calcite recrystallization rates and evidence for a rapid rise in seawater 
Mg over the last 10 million years. Geochimica et Cosmochimica Acta 70, 3883-3904.

Fantle M. S., DePaolo D. J. (2007) Ca isotopes in carbonate sediment and pore fluid from ODP Site 807A: The $\mathrm{Ca}^{2+}{ }_{(\mathrm{aq})}-$ calcite equilibrium fractionation factor and calcite recrystallization rates in Pleistocene sediments. Geochimica et Cosmochimica Acta 71, 2524-2546.

Fietzke J., Eisenhauer A. (2006) Determination of temperature-dependent stable strontium isotope $\left({ }^{88} \mathrm{Sr} /{ }^{86} \mathrm{Sr}\right)$ fractionation via bracketing standard MC-ICP-MS. Geochemistry Geophysics Geosystems 7. doi:10.1029/2006GC001243.

Friedman I., O’Neil J. R. (1977) Compilation of Stable Isotope Fractionation Factors of Geochemical Interest. Geol. Surv. Prof. Pap. 440-KK. US Govt. Printing Office.

Gradstein F., Ogg J., Smith A.(2004) A Geologic Time Scale 2004. 589p, Cambridge University Press, Cambridge.

Griffith E. M., Paytan A., Caldeira K., Bullen T. D., Thomas E. (2008a) A dynamic marine calcium cycle during the past 28 million years. Science 322, 1671-1674.

Griffith E. M., Paytan A., Kozdon R., Eisenhauer A., Ravelo A. C. (2008b) Influences on the fractionation of calcium isotopes in planktonic foraminifera. Earth and Planetary Science Letters 268, 124-136.

Gussone N., Eisenhauer A., Heuser A., Dietzel M., Bock B., Böhm F., Spero H. J., Lea D. W., Bijma J., Nägler T. F. (2003) Model for kinetic effects on calcium isotope fractionation $\left(\delta^{44} \mathrm{Ca}\right)$ in inorganic aragonite and cultured planktonic foraminifera. Geochimica et Cosmochimica Acta $\mathbf{6 7}$, 1375-1382.

Gussone N., Böhm F., Eisenhauer A., Dietzel M., Heuser A., Teichert B. M. A., Reitner J., Wörheide G., Dullo W.-C. (2005) Calcium isotope fractionation in calcite and aragonite. Geochimica et Cosmochimica Acta 69, 4485-4494.

Gussone N., Langer G., Thoms S., Nehrke G., Eisenhauer A., Riebesell U., Wefer G. (2006) Cellular calcium pathways and isotope fractionation in Emiliania huxleyi. Geology 34, 625-628.

Gussone N., Langer G., Geisen M., Steel B. A., Riebesell U. (2007) Calcium isotope fractionation in coccoliths of cultured Calcidiscus leptoporus, Helicosphaera carteri, Syracosphaera pulchra and Umbilicosphaera foliosa. Earth and Planetary Science Letters 260, 505-515.

Gussone N., Hönisch B., Heuser A., Eisenhauer A., Spindler M., Hemleben C. (2009) A critical evaluation of calcium isotope ratios in tests of planktonic foraminifers. Geochimica et Cosmochimica Acta 73, 7241-7255.

Halicz L., Segal I., Fruchter N., Stein M., Lazar B. (2008) Strontium stable isotopes fractionate in the soil environments? Earth and Planetary Science Letters 272, 406-411.

Jacobson A. D., Holmden C. (2008) $\delta^{44}$ Ca evolution in a carbonate aquifer and its bearing on the 
equilibrium isotope fractionation factor for calcite. Earth and Planetary Science Letters 270, 349-353.

Kerisit S., Parker S. C. (2004) Free energy of adsorption of water and metal ions on the [1014] calcite surface. Journal of the American Chemical Society 126, 10152-10161.

Kisakürek B., Eisenhauer A., Böhm F., Hathorne E. C., Erez J. (2011) Controls on Calcium Isotope Fractionation in Cultured Planktic Foraminifera, Globigerinoides ruber and Globigerinella siphonifera. Geochimica et Cosmochimica Acta 75, 427-443.

Knudson K. J., Williams H. M., Buikstra J. E., Tomczak P. D., Gordon G. W., Anbar A. D. (2010) Introducing $\delta^{88 / 86} \mathrm{Sr}$ analysis in archaeology: a demonstration of the utility of strontium isotope fractionation in paleodietary studies. Journal of Archaeological Science 37, 2352-2364.

Köhler-Rink S., Kühl M. (2005) The chemical microenvironment of the symbiotic planktonic foraminifer Orbulina universa. Marine Biology Research 1, 68-78.

Krabbenhöft A., Fietzke J., Eisenhauer A., Liebetrau V., Böhm F., Vollstaedt H. (2009)

Determination of radiogenic and stable strontium isotope ratios $\left({ }^{87} \mathrm{Sr} /{ }^{86} \mathrm{Sr} ; \delta^{88 / 86} \mathrm{Sr}\right)$ by thermal ionization mass spectrometry applying an ${ }^{87} \mathrm{Sr} /{ }^{84} \mathrm{Sr}$ double spike. Journal of Analytical Atomic Spectrometry 24, 1267-1271.

Krabbenhöft A., Eisenhauer A., Böhm F., Vollstaedt H., Fietzke J., Liebetrau V., Augustin N., Peucker-Ehrenbrink B., Müller M. N., Horn C., Hansen B. T., Nolte N., Wallmann K. (2010) Constraining the marine strontium budget with natural strontium isotope fractionations $\left({ }^{87} \mathrm{Sr} /{ }^{86} \mathrm{Sr} *, \delta^{88 / 86} \mathrm{Sr}\right)$ of carbonates, hydrothermal solutions and river waters. Geochimica et Cosmochimica Acta 74, 4097-4109.

Lea D. W., Martin P. A., Chan D. A., Spero H. J. (1995) Calcium uptake and calcification rate in the planktonic foraminifer Orbulina universa. The Journal of Foraminiferal Research 25, 14-23.

Lemarchand D., Wasserburg G., Papanastassiou D. (2004) Rate-controlled calcium isotope fractionation in synthetic calcite. Geochimica et Cosmochimica Acta 68, 4665-4678.

Li Y.-H., Gregory S. (1974) Diffusion of ions in sea water and in deep-sea sediments. Geochimica et Cosmochimica Acta 38, 703-714.

Liebetrau V., Eisenhauer A., Krabbenhöft A., Fietzke J., Böhm F., Rüggeberg A., Gürs K. (2009) New perspectives on the marine Sr-isotope record: $\delta^{88 / 86} \mathrm{Sr},{ }^{87} \mathrm{Sr} /{ }^{86} \mathrm{Sr} *$, and $\delta^{44 / 40} \mathrm{Ca}$ signatures of aragonitic molluscs throughout the last $27 \mathrm{Ma}$. Geochim. Cosmochim. Acta 73/13 Suppl.1, A762.

Marriott C. S., Henderson G. M., Belshaw N. S., Tudhope A.W. (2004) Temperature dependence of $\delta^{7} \mathrm{Li}, \delta^{44} \mathrm{Ca}$ and $\mathrm{Li} / \mathrm{Ca}$ during growth of calcium carbonate. Earth and Planetary Science Letters 222, 615-624. 
McArthur J. M., Howarth R. J. (2004) Strontium Isotope Stratigraphy. In: Gradstein F. M., Ogg J. G., Smith A. G. (eds.) A Geologic Time Scale, 96-105, Cambridge University Press, Cambridge. McArthur J. M., Rio D., Massari F., Castradori D., Bailey T., Thirlwall M., Houghton S. (2006) A revised Pliocene record for marine $-{ }^{87} \mathrm{Sr} /{ }^{86} \mathrm{Sr}$ used to date an interglacial event recorded in the Cockburn Island Formation, Antarctic Peninsula. Palaeogeography, Palaeoclimatology, Palaeoecology 242, 126-136.

Megyes T., Grósz T., Radnai T., Bakó I., Pálinkás G. (2004) Solvation of Calcium Ion in Polar Solvents: An X-ray Diffraction and ab Initio Study. The Journal of Physical Chemistry A 108, 7261-7271.

Miles G. A., Howe R. C. (1977) Biostratigraphic summary, Leg 37, Deep Sea Drilling Project. Initial Reports DSDP 37, 977-983.

Milliman J. D., Droxler A. W. (1996) Neritic and pelagic carbonate sedimentation in the marine environment: ignorance is not a bliss, Geologische Rundschau 85, 496-504.

Nier A. O. (1938) The isotopic constitution of strontium, barium, bismuth, thallium and mercury. Physical Review 5, 275-278.

Nürnberg D., Müller A., Schneider R. R. (2000) Paleo-sea surface temperature calculations in the equatorial east Atlantic from $\mathrm{Mg} / \mathrm{Ca}$ ratios in planktic foraminifera: A comparison to sea surface temperature estimates from $\mathrm{U} 37 \mathrm{~K}^{\prime}$, oxygen isotopes, and foraminiferal transfer function. Paleoceanography 15, 124-134.

Nürnberg D., Schönfeld J., Dullo W.-Chr. Rühlemann C. (2003): RV Sonne Cruise Report SO 164 RASTA. GEOMAR Report 109, 151p.

Ohno T., Hirata T. (2007) Simultaneous Determination of Mass-dependent Isotopic Fractionation and Radiogenic Isotope Variation of Strontium in Geochemical Samples by Multiple CollectorICP-Mass Spectrometry. Analytical Sciences 23, 1275-1280.

Raiteri P., Gale J. D., Quigley D., Rodger P. M. (2010) Derivation of an Accurate Force-Field for Simulating the Growth of Calcium Carbonate from Aqueous Solution: A New Model for the Calcite-Water Interface. The Journal of Physical Chemistry C 114, 5997-6010.

Reynard L. M., Day C. C., Henderson G. M. (2011) Large fractionation of calcium isotopes during cave-analogue calcium carbonate growth. Geochimica et Cosmochimica Acta 75, 3726-3740.

Richter F. M., Davis A. M., DePaolo D. J., Watson E. B. (2003) Isotope fractionation by chemical diffusion between molten basalt and rhyolite. Geochimica et Cosmochimica Acta 67, 3905-3923.

Rüggeberg A., Fietzke J., Liebetrau V., Eisenhauer A., Dullo W.-C., Freiwald A. (2008) Stable strontium isotopes $\left(\delta^{88 / 86} \mathrm{Sr}\right)$ in cold-water corals - A new proxy for reconstruction of intermediate ocean water temperatures. Earth and Planetary Science Letters 269, 570-575. 
Schiebel F. (2002) Planktic foraminiferal sedimentation and the marine calcite budget. Global Biogeochemical Cycles 16. doi:10.1029/2001GB001459.

Seward T. M., Henderson C. M. B., Charnock J. M., Driesner T. (1999) An EXAFS study of solvation and ion pairing in aqueous strontium solutions to $300^{\circ} \mathrm{C}$. Geochimica et Cosmochimica Acta 63, 2409-2418.

Steiger R. H., Jäger E. (1977) Subcommission on geochronology: convention on the use of decay constants in geochronology and cosmochronology. Earth and Planetary Science Letters 36, 359362.

Stevenson E. I., Burton K., Mokadem F., Parkinson I. J., Anand P., Hathorne E.C. (2010) The retrieval of marine weathering records preserved by strontium stable isotopes in foraminifera. EOS Trans. AGU 91 Fall Meeting Suppl., Abstract B21D-0343.

Tang J., Köhler S. J., Dietzel M. (2008a) $\mathrm{Sr}^{2+} / \mathrm{Ca}^{2+}$ and ${ }^{44} \mathrm{Ca} /{ }^{40} \mathrm{Ca}$ fractionation during inorganic calcite formation: I. Sr incorporation. Geochimica et Cosmochimica Acta 72, 3718-3732.

Tang J., Dietzel M., Böhm F., Köhler S. J., Eisenhauer A. (2008b) $\mathrm{Sr}^{2+} / \mathrm{Ca}^{2+}$ and ${ }^{44} \mathrm{Ca} /{ }^{40} \mathrm{Ca}$ fractionation during inorganic calcite formation: II. Ca isotopes. Geochimica et Cosmochimica Acta, 72: 3733-3745.

Tesoriero A. J., Pankow J. F. (1996) Solid solution partitioning of $\mathrm{Sr}^{2+}, \mathrm{Ba}^{2+}$, and $\mathrm{Cd}^{2+}$ to calcite. Geochimica et Cosmochimica Acta 60, 1053-1063.

Tofteberg T., Öhrn A., Karlström G. (2006) Combined quantum chemical statistical mechanical simulations of $\mathrm{Mg}^{2+}, \mathrm{Ca}^{2+}$ and $\mathrm{Sr}^{2+}$ in water. Chemical Physics Letters 429, 436-439.

Watson E. B. (2004) A conceptual model for near-surface kinetic controls on the trace-element and stable isotope composition of abiogenic calcite crystals. Geochimica et Cosmochimica Acta 68, 1473-1488.

Watson E. B., Müller T. (2009) Non-equilibrium isotopic and elemental fractionation during diffusion-controlled crystal growth under static and dynamic conditions. Chemical Geology 267, 111-124.

Wolf-Gladrow D., Riebesell U. (1997) Diffusion and reactions in the vicinity of plankton: A refined model for inorganic carbon transport. Marine Chemistry 59, 17-34.

Wombacher F., Eisenhauer A., Böhm F., Gussone N., Regenberg M., Dullo W.-C., Rüggeberg A. (2011) Magnesium stable isotope fractionation in marine biogenic calcite and aragonite. Geochimica et Cosmochimica Acta 75, 5797-5878.

Young E. D., Galy A., Nagahara H. (2002) Kinetic and equilibrium mass-dependent isotope fractionation laws in nature and their geochemical and cosmochemical significance. Geochimica et Cosmochimica Acta 66, 1095-1104. 
Zeebe R. E., Wolf-Gladrow D. (2001) $\mathrm{CO}_{2}$ in Seawater: Equilibrium, Kinetics, Isotopes. Elsevier Oceanography Series, 65, 346 p., Elsevier, Amsterdam. 


\section{FIGURE CAPTIONS}

Fig. 1: Rate dependence of strontium isotope fractionation in experimental inorganic calcite. Precipitation rates are taken from Tang et al. (2008b). Dashed lines represent 95\% confidence belts. Two samples of natural calcite that formed in ocean crust basalts with very low precipitation rates are shown for comparison, but not included in the regression. Precipitation rates for these two samples were estimated from the measured $\mathrm{Sr} / \mathrm{Ca}$ ratios using the rate dependence from Tang et al. (2008a). The strontium isotope value measured for G. ruber and G. sacculifer is indicated by the arrow. Error bars represent average 2SEM of repeated sample measurements.

Fig. 2: Linear correlation of strontium isotope fractionation and the $\mathrm{Sr} / \mathrm{Ca}$ distribution coefficient $\left(\mathrm{K}_{d}^{\mathrm{Sr}}\right)$ in experimental inorganic calcite. Calcites from ocean crust basalts plot close to the extrapolated regression line. The values from planktic foraminifera plot within the $95 \%$ confidence belt (dashed lines). $\mathrm{K}_{d}{ }^{\text {Sr }}$ values of the foraminifera are from Elderfield et al. (2000) and represent average values of a range of core top samples $\left(\mathrm{K}_{d}^{\mathrm{Sr}}=0.167\right.$ for $G$. ruber, $\mathrm{K}_{d}{ }^{\mathrm{Sr}}=0.163$ for $G$. sacculifer). Error bars represent average 2SEM of repeated sample measurements.

Fig. 3: Linear correlation of strontium and calcium isotope fractionation in experimental inorganic calcite. Dashed lines represent 95\% confidence belts. Calcites from ocean crust basalts plot close to the extrapolated regression line. Foraminiferal data show a slight enrichment of ${ }^{44} \mathrm{Ca}$ compared to the value expected from the inorganic regression. The calcium isotope values are averages, with $\Delta^{44 / 40} \mathrm{Ca}_{\text {carb-aq }}=-1.14 \%$ for cultured G. ruber, experiments at $27-30^{\circ} \mathrm{C}, 35 \mathrm{psu}, \mathrm{pH}$ of 8.3 to 8.4 , $\delta^{44 / 40} \mathrm{Ca}$ of seawater $=1.84 \%$ o (SRM915a) from Kisakürek et al. $(2011) ; \Delta^{44 / 40} \mathrm{Ca}_{\text {carb-aq }}=-1.10 \%$ or $G$. sacculifer from culturing experiments and sediment trap samples, $27-28^{\circ} \mathrm{C}$ (Gussone et al., 2009; Griffith et al., 2008b). Error bars represent average 2SEM of repeated sample measurements.

Fig. 4: Model calculations of the steady state isotope fractionation between bulk fluid and the liquid-crystal boundary $\left(\Delta^{44 / 40} \mathrm{Ca}_{\mathrm{DBL}}\right.$ and $\left.\Delta^{88 / 86} \mathrm{Sr}_{\mathrm{DBL}}\right)$ in a diffusive boundary layer of $50 \mu \mathrm{m}$ width around a growing calcite crystal. Crystal growth rates include the typical range of experimental and biogenic calcite growth as indicated by the arrow. Calcite growth rates in seawater are limited by the availability of carbonate ions. The plotted range includes the highest possible rate in normal marine settings for BT=50 $\mu \mathrm{m}$ (see Appendix, Table A2). The strontium curve is calculated for normal seawater $\mathrm{Ca}^{2+}$ concentration. Calcium calculations are shown for seawater concentration and 
ten times seawater concentration. The curves include the effects of diffusive isotope fractionation and depletion of the isotope species which is preferentially taken up into the crystal. The effect of diffusive fractionation (Bourg et al., 2010) is shown for comparison, calculated for a normal seawater $\mathrm{Ca}^{2+}$ concentration.

Fig. 5: Modelled correlation between strontium and calcium isotope fractionation due to diffusion and isotope depletion in a diffusive boundary layer adjacent to calcite crystals growing at rates between $10^{2}$ and $10^{4.7} \mu \mathrm{mol} / \mathrm{m}^{2} / \mathrm{h}$, with boundary layer thicknesses ranging from 50 to $500 \mu \mathrm{m}$. Numbers above and below the graph indicate the Ca depletion $\left(\mathrm{C}^{\mathrm{Ca}} / \mathrm{C}^{\mathrm{Ca}}{ }_{0}\right)$ and $\mathrm{Sr}$ depletion $\left(\mathrm{C}^{\mathrm{Sr}} / \mathrm{C}^{\mathrm{Sr}}\right)$ in the DBL, respectively. Note that in seawater the Ca depletion in the DBL is limited to $\mathrm{C}^{\mathrm{Ca}} / \mathrm{C}^{\mathrm{Ca}}{ }_{0}$ values $>0.95$ by the availability of carbonate ions. 
Table 1: Inorganic calcite precipitation experiments.

\begin{tabular}{|l|c|c|c|c|c|c|c|c|c|c|}
\hline $\begin{array}{c}\text { Experiment } \\
\#\end{array}$ & $\begin{array}{c}\log (\mathrm{R}) \\
\left(\mu \mathrm{mol} / \mathrm{m}^{2} / \mathrm{h}\right)\end{array}$ & $\begin{array}{c}\Delta^{44 / 40} \mathrm{Ca}_{\text {carb-aq }} \\
(\%)\end{array}$ & $\mathrm{f}_{\mathrm{Ca}}$ & $\begin{array}{c}\Delta^{44 / 40} \mathrm{Ca}_{\mathrm{RC}} \\
(\%)\end{array}$ & $\mathrm{K}_{\mathrm{d}}^{\mathrm{Sr}}$ & $\begin{array}{c}\mathrm{Sr}_{\mathrm{cc}} \\
(\mu \mathrm{g} / \mathrm{g})\end{array}$ & $\begin{array}{c}\mathrm{M}_{\mathrm{cc}} \\
(\mathrm{mg})\end{array}$ & $\mathrm{Sl}_{\mathrm{cc}}$ & $\begin{array}{c}\Delta^{88 / 86} \mathrm{Sr}_{\mathrm{carb}-\mathrm{aq}} \\
(\%)\end{array}$ & ${ }^{87} \mathrm{Sr} /{ }^{86} \mathrm{Sr}$ \\
\hline $11(\mathrm{C} 29)$ & 4.21 & $-1.50 \pm 0.19$ & 0.89 & -1.59 & 0.16 & 1477 & 510 & 1.21 & $-0.292 \pm 0.034$ & 0.707854 \\
\hline $14(\mathrm{C} 32)$ & 3.02 & $-0.80 \pm 0.08$ & 0.90 & -0.84 & 0.09 & 830 & 480 & 0.94 & $-0.164 \pm 0.020$ & 0.707852 \\
\hline $15(\mathrm{C} 34)$ & 2.25 & $-0.62 \pm 0.16$ & 0.85 & -0.67 & 0.07 & 600 & 730 & 0.66 & $-0.153 \pm 0.002$ & 0.707849 \\
\hline $16(\mathrm{C} 35)$ & 3.34 & $-1.03 \pm 0.12$ & 0.93 & -1.07 & 0.11 & 932 & 370 & 0.89 & $-0.199 \pm 0.019$ & 0.707836 \\
\hline $17(\mathrm{C} 37)$ & 2.39 & $-0.51 \pm 0.01$ & 0.94 & -0.53 & 0.06 & 525 & 310 & 0.65 & $-0.086 \pm 0.002$ & 0.708709 \\
\hline $19(\mathrm{C} 39)$ & 4.18 & $-1.37 \pm 0.15$ & 0.91 & -1.43 & 0.17 & 1503 & 430 & 1.21 & $-0.263 \pm 0.012$ & 0.708701 \\
\hline
\end{tabular}

Experiment numbers, precipitation rates $(\log (\mathrm{R}))$, calcium isotope fractionation between fluid and calcite $\left(\Delta^{44 / 40} \mathrm{Ca}_{\text {carb-aq }}\right.$ with $2 \mathrm{SEM}$ errors), strontium distribution coefficients $\left(\mathrm{K}_{\mathrm{d}}^{\mathrm{Sr}}\right)$, strontium concentration in calcite $\left(\mathrm{Sr}_{\mathrm{cc}}\right)$, total mass of calcite precipitated $\left(\mathrm{M}_{\mathrm{cc}}\right)$, and the critical saturation index for the precipitation of calcite $\left(\mathrm{SI}_{\mathrm{cc}}\right)$ are from Tang et al. $(2008 \mathrm{a}, \mathrm{b})$. All experiments were carried out at $25^{\circ} \mathrm{C}$, a pH of 8.3 and an ionic strength of about $0.035 \mathrm{M}$. Initial $\mathrm{Ca}^{2+}$ and $\mathrm{Sr}^{2+}$ concentrations in the precipitating fluid $(5 \mathrm{~L})$ were $9.9 \mathrm{mM}$ and $95 \mu \mathrm{M}$, respectively. Rayleigh fractionation corrected calcium isotope values were calculated from the remaining $\mathrm{Ca}$ fraction in solution ( $\left.\mathrm{f}_{\mathrm{Ca}}\right)$ using $\Delta^{44 / 40} \mathrm{Ca}_{\mathrm{RC}}=\left(\ln \left(\mathrm{f}_{\mathrm{Ca}}{ }^{*} \Delta^{44 / 40} \mathrm{Ca}_{\text {carb-aq }} / 1000-\Delta^{44 / 40} \mathrm{Ca}_{\text {carb-aq }} / 1000+\mathrm{f}_{\mathrm{Ca}}\right) / \ln \left(\mathrm{f}_{\mathrm{Ca}}\right)-1\right){ }^{*} 1000 . \mathrm{Sr}^{2+}$ consumption was less than $2 \%$ in all experiments, therefore no Rayleigh correction was applied. Strontium isotope fractionation $\left(\Delta^{88 / 86} \mathrm{Sr}_{\text {carb-aq }}\right.$ with $2 \mathrm{SEM}$ errors from repeated analyses, $\mathrm{n}=2$ for all samples) is the difference between the measured calcite sample composition and the dissolved $\mathrm{Sr}^{2+}$ composition in the fluid, with $\delta^{88 / 86} \mathrm{Sr}_{\text {fluid }}=0.156 \pm 0.005 \%$ (relative to SRM 987). Precision (1sd) is: $\log (\mathrm{R}) \pm 0.12, \mathrm{~K}_{\mathrm{d}}^{\mathrm{Sr}} \pm 0.01,{ }^{87} \mathrm{Sr} /{ }^{86} \mathrm{Sr} \pm 10^{-5}$. 
Table 2: Inorganic calcite cements from ocean crust basalt.

\begin{tabular}{|c|c|c|c|c|c|c|c|c|}
\hline Core Interval & $\begin{array}{c}\text { Basement } \\
\text { Depth }(\mathrm{m})\end{array}$ & $\begin{array}{c}\delta^{18} \mathrm{O} \\
(\% \circ \mathrm{VPDB})\end{array}$ & $\begin{array}{c}\mathrm{T}_{\text {calc }} \\
\left({ }^{\circ} \mathrm{C}\right)\end{array}$ & ${ }^{87} \mathrm{Sr} /{ }^{86} \mathrm{Sr}$ & $\begin{array}{c}{ }^{87} \mathrm{Sr} \text { Age } \\
(\mathrm{Ma})\end{array}$ & $\begin{array}{c}\mathrm{Sr} / \mathrm{Ca}_{\mathrm{cc}} \\
(\mathrm{mmol} / \mathrm{mol})\end{array}$ & $\begin{array}{c}\Delta^{44 / 40} \mathrm{Ca} \\
(\% 0)\end{array}$ & $\begin{array}{c}\Delta^{88 / 86} \mathrm{Sr} \\
(\% 0)\end{array}$ \\
\hline $335-7-3,105 \mathrm{~cm}$ & 17 & 3.22 & 2 & 0.70896 & $6.8 \pm 0.6$ & 0.33 & -0.17 & -0.058 \\
\hline $335-9-1,50 \mathrm{~cm}$ & 33 & 3.30 & 1 & 0.70897 & $6.5 \pm 0.5$ & 0.30 & -0.09 & -0.049 \\
\hline
\end{tabular}

Both cores are from DSDP Leg 37. Oxygen isotopes, ${ }^{87} \mathrm{Sr} /{ }^{86} \mathrm{Sr}, \mathrm{Sr} / \mathrm{Ca}$ ratios in the calcite $\left(\mathrm{Sr} / \mathrm{Ca}_{\mathrm{cc}}\right)$, and calcium isotopes are from Böhm et al. (2009). $\mathrm{T}_{\text {calc }}$ is the calcite formation temperature calculated from $\delta^{18} \mathrm{O}$ assuming a $\delta^{18} \mathrm{O}$ of seawater of $-0.5 \%$ (VSMOW) and applying the calibration of Friedman and O'Neil (1977). The ${ }^{87} \mathrm{Sr}$ ages were calculated from the measured ${ }^{87} \mathrm{Sr} /{ }^{86} \mathrm{Sr}$ ratios, adjusted to a ${ }^{87} \mathrm{Sr} /{ }^{86} \mathrm{Sr}_{\mathrm{SRM} 987}$ of 0.710248 , by comparing with the Strontium Isotope Stratigraphy of McArthur and Howarth (2004). The $\Delta^{44 / 40} \mathrm{Ca}$ value is the difference between the measured $\delta^{44 / 40} \mathrm{Ca}$ of the calcite and seawater with an estimated $\delta^{44 / 40} \mathrm{Ca}$ at the time of calcite formation (ca. $7 \mathrm{Ma}$ ) of $1.9 \pm 0.1 \%$ o (SRM915a) (e.g. Griffith et al., 2008a). The $\Delta^{88 / 86} \mathrm{Sr}$ values were calculated accordingly, assuming that seawater at $7 \mathrm{Ma}$ had the same $\delta^{88 / 86} \mathrm{Sr}$ as today $(0.386 \%$ SRM987, Krabbenhöft et al., 2009). Analytical precision (1sd) is $\pm 0.03 \%$ or for $\delta^{18} \mathrm{O}, \pm 10^{-5}$ for ${ }^{87} \mathrm{Sr} /{ }^{86} \mathrm{Sr}, \pm 0.01 \mathrm{mmol} / \mathrm{mol}$ for $\mathrm{Sr} / \mathrm{Ca}_{\mathrm{cc}}, \pm 0.1 \%$ for $\delta^{44 / 40} \mathrm{Ca}$, and $\pm 0.01 \%$ for $\delta^{88 / 86} \mathrm{Sr}$. 
Table 3: Globigerionides ruber and Globigerinoides sacculifer samples.

\begin{tabular}{|l|c|c|c|c|c|} 
Sample & $\begin{array}{c}\text { Depth } \\
(\mathrm{cm})\end{array}$ & $\begin{array}{c}\text { Age } \\
(\mathrm{ka})\end{array}$ & $\begin{array}{c}\mathrm{T} \\
\left({ }^{\circ} \mathrm{C}\right)\end{array}$ & $\begin{array}{c}\Delta^{88 / 86} \mathrm{Sr}_{\text {carb-aq }} \\
(\%)\end{array}$ & ${ }^{87} \mathrm{Sr} /{ }^{86} \mathrm{Sr}$ \\
\hline HFB9r & 10 & 1.4 & 29.9 & -0.242 & 0.709180 \\
\hline HFB8r & 26 & 4.1 & 30.3 & -0.256 & 0.709171 \\
\hline HFB7r & 43 & 7.0 & 30.5 & -0.243 & 0.709177 \\
\hline Average Holocene G. ruber & $-\mathbf{0 . 2 4 7}$ & $\mathbf{0 . 7 0 9 1 7 6}$ \\
\hline HFB2r & 106 & 22 & 26.9 & -0.247 & 0.709168 \\
\hline HFB1r & 116 & 25 & 26.5 & -0.254 & 0.709175 \\
\hline 116rub & 116 & 25 & 26.5 & -0.261 & 0.709174 \\
\hline Average glacial G. ruber & & $-\mathbf{0 . 2 5 4}$ & $\mathbf{0 . 7 0 9 1 7 3}$ \\
\hline HFB10s & 10 & 1.4 & 27.0 & -0.253 & 0.709185 \\
\hline 10sacc & 10 & 1.4 & 27.0 & -0.259 & 0.709162 \\
\hline HFB11s & 26 & 4.1 & n.a. & -0.243 & 0.709171 \\
\hline HFB12s & 43 & 7.0 & 26.6 & -0.245 & 0.709159 \\
\hline 43sacc & 43 & 7.0 & 26.6 & -0.242 & 0.709159 \\
\hline Average Holocene G. sacculifer & $-\mathbf{- 0 . 2 4 8}$ & $\mathbf{0 . 7 0 9 1 6 7}$ \\
\hline
\end{tabular}

Temperatures were calculated from $\mathrm{Mg} / \mathrm{Ca}$ ratios of specimens of the two species picked from the same samples using the temperature calibration of Nürnberg et al. (2000); depositional ages are based on oxygen isotope analyses of benthic foraminifera (C. Horn, doctoral thesis, University of Kiel). Analytical precision (1sd) is $\pm 0.01 \%$ or $\delta^{88 / 86} \mathrm{Sr}$, and $\pm 10^{-5}$ for ${ }^{87} \mathrm{Sr} /{ }^{86} \mathrm{Sr}$. Standard error of the $\delta^{88 / 86} \mathrm{Sr}$ mean values (2SEM) is $\pm 0.009 \%$ for Holocene G. ruber, $\pm 0.008 \%$ or glacial G. ruber, and $\pm 0.006 \%$ for G. sacculifer. All $\Delta^{88 / 86} \mathrm{Sr}_{\text {carb-aq }}$ values were calculated with a seawater $\delta^{88 / 86} \mathrm{Sr}$ of $0.386 \pm 0.08 \%$ o (Krabbenhöft et al., 2009). 


\section{Appendix}

\section{Derivation of steady state equations describing isotope and concentration effects in the diffusive boundary layer (DBL)}

We derive steady state equations for the DBL concentrations and isotope ratios of $\mathrm{Ca}^{2+}$ and $\mathrm{Sr}^{2+}$ for calcite growing in aqueous solution. Our equations are based on Equations 6 and 7 of Watson and Müller (2009) which describe 1-dimensional steady state diffusion in a diffusive boundary layer. The two equations quantify the concentration of a solute at the liquid-crystal interface and are combined in Eq. (A1). The left hand side of Eq. (A1) describes the transport of ions from the fluid into the crystal. In steady state this flux is balanced by a diffusive flux from the bulk solution to the liquid-crystal interface (right hand side).

$$
\left(\mathrm{C}_{\mathrm{L}}-\mathrm{C}_{\mathrm{X}}\right) * \mathrm{~A} * \delta \mathrm{t} * \mathrm{~V}=\mathrm{A} * \delta \mathrm{t} * \mathrm{D}\left(\mathrm{C}_{\mathrm{L}}-\mathrm{C}_{0}\right) / \mathrm{BT}
$$

$\mathrm{C}_{\mathrm{L}}, \mathrm{C}_{0}$ and $\mathrm{C}_{\mathrm{X}}$ are the concentrations of the ion of interest in the fluid of the liquid-crystal interface, in the bulk fluid, and in the crystal, respectively (in $\mathrm{mmol} / \mathrm{cm}^{3}$ ). For calcite growing in aqueous solution these can be the concentrations of $\mathrm{Ca}^{2+}$ or $\mathrm{CO}_{3}{ }^{2-}$. A is the growing surface area of the crystal $\left(\mathrm{cm}^{2}\right), \delta \mathrm{t}$ is a short time increment $(\mathrm{s}), \mathrm{V}$ is the radial crystal extension velocity $(\mathrm{cm} / \mathrm{s}), \mathrm{D}$ is the diffusion coefficient $\left(\mathrm{cm}^{2} / \mathrm{s}\right)$, and BT is the thickness of the diffusive boundary layer $(\mathrm{cm})$. Equation $\mathrm{A} 1$ can be solved for $\mathrm{C}_{\mathrm{L}}$, the solute concentration at the liquid-crystal interface:

$$
\mathrm{C}_{\mathrm{L}}=\left(\mathrm{C}_{0} * \mathrm{D}-\mathrm{V} * \mathrm{BT} * \mathrm{C}_{\mathrm{X}}\right) /(\mathrm{D}-\mathrm{V} * \mathrm{BT})
$$

The concentration of an isotope or a trace element substituting for a major ion (e.g. ${ }^{44} \mathrm{Ca}$ or $\mathrm{Sr}$ substituting for $\mathrm{Ca}$ in calcite) can be calculated with the same equation.

$$
\mathrm{C}_{\mathrm{L}}^{44}=\left(\mathrm{C}^{44}{ }_{0} * \mathrm{D}^{44}-\mathrm{V} * \mathrm{BT} * \mathrm{C}^{44} \mathrm{x}\right) /\left(\mathrm{D}^{44}-\mathrm{V} * \mathrm{BT}\right)
$$

Equation (A3) can be rewritten using the following definitions

$\mathrm{D}^{44}=\alpha_{\mathrm{d}}^{44} * \mathrm{D}_{\mathrm{Ca}}$

$\mathrm{C}^{44}{ }_{0}=\mathrm{C}^{\mathrm{Ca}} * \mathrm{R}^{44}{ }_{\mathrm{fl}}$

$\mathrm{C}^{44}{ }_{\mathrm{x}} / \mathrm{C}_{\mathrm{x}}^{\mathrm{Ca}}=\alpha^{44}{ }_{\mathrm{x}} * \mathrm{C}_{\mathrm{L}}^{44} / \mathrm{C}_{\mathrm{L}}^{\mathrm{Ca}}$

where $\alpha^{44}{ }_{\mathrm{x}}$ is the ${ }^{44} \mathrm{Ca} /{ }^{40} \mathrm{Ca}$ isotope fractionation factor between fluid and crystal, $\alpha^{44}{ }_{\mathrm{d}}$ is the isotope fractionation during diffusive transport of ions, and $\mathrm{R}^{44}{ }_{\mathrm{fl}}$ is the molar fraction of ${ }^{44} \mathrm{Ca}$ relative to total $\mathrm{Ca}$ in the bulk fluid $\left(\mathrm{C}^{\mathrm{Ca}}\right)$ :

$\mathrm{C}_{\mathrm{L}}^{44}=\left(\mathrm{R}_{\mathrm{fl}}^{44} * \mathrm{C}_{0}^{\mathrm{Ca}} * \alpha_{\mathrm{d}}^{44} * \mathrm{D}_{\mathrm{Ca}}-\mathrm{V} * \mathrm{BT} * \alpha_{\mathrm{x}}^{44} * \mathrm{C}_{\mathrm{X}}^{\mathrm{Ca}} * \mathrm{C}_{\mathrm{L}}^{44} / \mathrm{C}_{\mathrm{L}}^{\mathrm{Ca}}\right) /\left(\alpha_{\mathrm{d}}^{44} * \mathrm{D}_{\mathrm{Ca}}-\mathrm{V} * \mathrm{BT}\right)$

Solving for $\mathrm{C}^{44}$ and dividing by $\mathrm{C}^{\mathrm{Ca}}{ }_{\mathrm{L}}$ quantifies the molar fraction of ${ }^{44} \mathrm{Ca}$ at the liquid-crystal interface:

$$
\mathrm{C}_{\mathrm{L}}^{44} / \mathrm{C}_{\mathrm{L}}^{\mathrm{Ca}}=\left(\mathrm{R}_{\mathrm{fl}}^{44} * \mathrm{C}_{0}^{\mathrm{Ca}}{ }_{0} * \alpha^{44}{ }_{\mathrm{d}} * \mathrm{D}_{\mathrm{Ca}}\right) /\left(\mathrm{V} * \mathrm{BT} *\left(\alpha^{44}{ }_{\mathrm{x}} * \mathrm{C}_{\mathrm{X}}^{\mathrm{Ca}}-\mathrm{C}_{\mathrm{L}}^{\mathrm{Ca}}\right)+\alpha^{44}{ }_{\mathrm{d}} * \mathrm{D}_{\mathrm{Ca}} * \mathrm{C}_{\mathrm{L}}^{\mathrm{Ca}}\right)
$$


The isotope effect of the diffusive boundary layer can be described by the offset in the isotopic composition $\left(\delta^{44 / 40} \mathrm{Ca}\right)$ between the bulk fluid and the liquid-crystal interface as

$$
\Delta^{44 / 40} \mathrm{Ca}_{\mathrm{DBL}}=\delta^{44 / 40} \mathrm{Ca}_{\mathrm{L}}-\delta^{44 / 40} \mathrm{Ca}_{0} \approx\left(\mathrm{C}_{\mathrm{L}}^{44} / \mathrm{C}_{\mathrm{L}}^{\mathrm{Ca}} / \mathrm{R}_{\mathrm{fl}}^{44}-1\right) * 1000
$$

Equation (A6) is an approximation based on the assumption that $\mathrm{C}^{40}{ }_{\mathrm{L}} / \mathrm{C}^{40}{ }_{0}=\mathrm{C}^{\mathrm{Ca}} / \mathrm{C}^{\mathrm{Ca}}{ }_{0}$, i.e. that the concentration gradient from bulk solution to the liquid-crystal boundary is very similar for total calcium and for ${ }^{40} \mathrm{Ca}$. Because there is isotope fractionation in the $\mathrm{DBL}$, the ${ }^{44} \mathrm{Ca} /{ }^{40} \mathrm{Ca}$ ratio and consequently the ${ }^{40} \mathrm{Ca} / \mathrm{Ca}$ ratio are changed resulting in $\mathrm{C}^{40}{ }_{\mathrm{L}} / \mathrm{C}^{\mathrm{Ca}}{ }_{\mathrm{L}}=\mathrm{x} * \mathrm{C}^{40} / \mathrm{C}^{\mathrm{Ca}}{ }_{0}$, where $\mathrm{x}$ is the error introduced by the approximation. Neglecting other calcium isotopes, which account for only $0.97 \%$ of total calcium, we estimate $\mathrm{x}=\left(\mathrm{R}^{44 / 40}{ }_{\mathrm{fl}}+1\right) /\left(\alpha_{\mathrm{DBL}} * \mathrm{R}^{44 / 40}{ }_{\mathrm{fl}}+1\right)$ from the natural molar ${ }^{44} \mathrm{Ca} /{ }^{40} \mathrm{Ca}$ ratio, $\mathrm{R}^{44 / 40}$ fl and the ${ }^{44} \mathrm{Ca} /{ }^{40} \mathrm{Ca}$ fractionation in the DBL, $\alpha_{\mathrm{DBL}}$. For $\alpha_{\mathrm{DBL}}=1.001(1 \% \mathrm{o})$ and $\mathrm{R}^{44 / 40} \mathrm{fl} \approx$ 0.02152 we get $\mathrm{x}=0.99998$. That means $\mathrm{C}^{40} \mathrm{~L}$ is $0.02 \%$ more depleted with respect to the bulk concentration $\left(\mathrm{C}^{40}{ }_{0}\right)$ than total calcium. The $\Delta^{44 / 40} \mathrm{Ca}_{\mathrm{DBL}}$ value calculated with Eq. (A6) therefore slightly underestimates the true DBL isotope effect, but the error is negligible.

Combining Eqs. (A5) and (A6) results in

$$
\Delta^{44 / 40} \mathrm{Ca}_{\mathrm{DBL}}=\left(\mathrm{C}^{\mathrm{Ca}}{ }_{0} * \alpha^{44}{ }_{\mathrm{d}} * \mathrm{D}_{\mathrm{Ca}} /\left(\mathrm{V} * \mathrm{BT} *\left(\alpha^{44}{ }_{\mathrm{x}} * \mathrm{C}^{\mathrm{Ca}}{ }_{\mathrm{X}}-\mathrm{C}_{\mathrm{L}}^{\mathrm{Ca}}\right)+\alpha^{44}{ }_{\mathrm{d}} * \mathrm{D}_{\mathrm{Ca}} * \mathrm{C}_{\mathrm{L}}^{\mathrm{Ca}}\right)-1\right) * 1000
$$

$\mathrm{C}^{\mathrm{Ca}}$ can be calculated for a calcite crystal growing in aqueous solution using Eq. (A2) with given values of $\mathrm{BT}, \mathrm{V}, \mathrm{C}^{\mathrm{Ca}}, \alpha^{44}{ }_{\mathrm{d}}, \alpha^{44}{ }_{\mathrm{x}}, \mathrm{D}_{\mathrm{Ca}}$, and with the concentration of calcium in calcite $\left(\mathrm{C}^{\mathrm{Ca}}{ }_{\mathrm{x}}\right)$ of 27.1 $\mathrm{mmol} / \mathrm{cm}^{3}$. This value can be assumed to be sufficiently invariant in pure calcite, where only trace amounts of $\mathrm{Ca}$ are substituted by other cations (e.g. Sr).

In analogy to Eq. (A3) we quantify the concentrations of total $\mathrm{Sr}$ and ${ }^{88} \mathrm{Sr}$ at the liquid-crystal interface of a calcite crystal in Eqs. (A8) and (A9), respectively:

$$
\mathrm{C}_{\mathrm{L}}^{\mathrm{Sr}}=\left(\mathrm{C}_{0}^{\mathrm{Sr}} * \mathrm{D}_{\mathrm{Sr}}-\mathrm{V} * \mathrm{BT} * \mathrm{C}_{\mathrm{X}}^{\mathrm{Sr}}\right) /\left(\mathrm{D}_{\mathrm{Sr}}-\mathrm{V} * \mathrm{BT}\right)
$$

where $\mathrm{D}_{\mathrm{Sr}}$ is the diffusion coefficient of $\mathrm{Sr}, \mathrm{C}^{\mathrm{Sr}}$ and $\mathrm{C}^{\mathrm{Sr}}$ are the concentrations of $\mathrm{Sr}\left(\mathrm{mmol} / \mathrm{cm}^{3}\right)$ in the calcite crystal and in the bulk fluid, respectively. For ${ }^{88} \mathrm{Sr}$ we can write:

$$
\mathrm{C}_{\mathrm{L}}^{88}=\left(\mathrm{C}^{88}{ }_{0} * \mathrm{D}_{88}-\mathrm{V} * \mathrm{BT} * \mathrm{C}^{88} \mathrm{x}\right) /\left(\mathrm{D}_{88}-\mathrm{V} * \mathrm{BT}\right)
$$

As for the calcium isotopes we can define:

$$
\begin{aligned}
& \mathrm{D}^{88}=\alpha^{88}{ }_{\mathrm{d}} * \mathrm{D}_{\mathrm{Sr}} \\
& \mathrm{C}^{88}{ }_{0}=\mathrm{C}^{\mathrm{Sr}}{ }_{0} * \mathrm{R}^{88}{ }_{\mathrm{fl}} \\
& \mathrm{C}^{88}{ }_{\mathrm{x}} / \mathrm{C}^{\mathrm{Sr}}{ }_{\mathrm{x}}=\alpha^{88}{ }_{\mathrm{x}} * \mathrm{C}^{88}{ }_{\mathrm{L}} / \mathrm{C}_{\mathrm{L}}^{\mathrm{Sr}}
\end{aligned}
$$

Where $\alpha^{88}{ }_{\mathrm{x}}$ and $\alpha^{88}{ }_{\mathrm{d}}$ are the ${ }^{88} \mathrm{Sr}{ }^{86} \mathrm{Sr}$ fractionation factors for crystallisation and diffusion, respectively. With that Eq. (A9) can be rearranged, similar to Eq. (A5), to

$$
\mathrm{C}^{88}{ }_{\mathrm{L}} / \mathrm{C}_{\mathrm{L}}^{\mathrm{Sr}}=\left(\mathrm{R}^{88}{ }_{\mathrm{fl}} * \mathrm{C}^{\mathrm{Sr}} * \alpha^{88}{ }_{\mathrm{d}} * \mathrm{D}_{\mathrm{Sr}}\right) /\left(\mathrm{V} * \mathrm{BT} *\left(\alpha^{88}{ }_{\mathrm{x}} * \mathrm{C}_{\mathrm{X}}^{\mathrm{Sr}}-\mathrm{C}_{\mathrm{L}}^{\mathrm{Sr}}\right)+\alpha_{\mathrm{d}}^{88} * \mathrm{D}_{\mathrm{Sr}} * \mathrm{C}_{\mathrm{L}}^{\mathrm{Sr}}\right)
$$


The concentration of $\mathrm{Sr}$ in calcite, $\mathrm{C}^{\mathrm{Sr}}$, depends on the $\mathrm{Sr} / \mathrm{Ca}$ partition coefficient between calcite and solution:

$\mathrm{K}_{\mathrm{d}}=\mathrm{C}^{\mathrm{Sr}}{ }_{\mathrm{X}} / \mathrm{C}^{\mathrm{Ca}}{ }_{\mathrm{X}} / \mathrm{C}_{\mathrm{L}}^{\mathrm{Sr}} / \mathrm{C}^{\mathrm{Ca}}{ }_{\mathrm{L}}$

With that Eq. (A8) can be rearranged to

$$
\mathrm{C}_{\mathrm{L}}^{\mathrm{Sr}}=\mathrm{C}_{\mathrm{L}}^{\mathrm{Ca}} * \mathrm{D}_{\mathrm{Sr}} * \mathrm{C}_{0}^{\mathrm{Sr}} /\left(\mathrm{V} * \mathrm{BT} *\left(\mathrm{~K}_{\mathrm{d}} * \mathrm{C}_{\mathrm{X}}^{\mathrm{Ca}}-\mathrm{C}_{\mathrm{L}}^{\mathrm{Ca}}\right)+\mathrm{C}_{\mathrm{L}}^{\mathrm{Ca}} * \mathrm{D}_{\mathrm{Sr}}\right)
$$

Combining and rearranging Eqs. (A10) and (A11) in analogy to Eq. (A6) results in

$$
\begin{aligned}
& \Delta^{88 / 86} \mathrm{Sr}_{\mathrm{DBL}}=\left(\left(\mathrm{V} * \mathrm{BT} * \alpha^{88}{ }_{\mathrm{d}} *\left(\mathrm{~K}_{\mathrm{d}} * \mathrm{C}_{\mathrm{X}}^{\mathrm{Ca}}-\mathrm{C}_{\mathrm{L}}^{\mathrm{Ca}}\right)+\alpha^{88}{ }_{\mathrm{d}} * \mathrm{D}_{\mathrm{Sr}} * \mathrm{C}_{\mathrm{L}}^{\mathrm{Ca}}\right) /\right. \\
&\left.\left(\mathrm{V} * \mathrm{BT} *\left(\alpha^{88}{ }_{\mathrm{x}} * \mathrm{~K}_{\mathrm{d}} * \mathrm{C}_{\mathrm{X}}^{\mathrm{Ca}}-\mathrm{C}_{\mathrm{L}}^{\mathrm{Ca}}\right)+\alpha^{88}{ }_{\mathrm{d}} * \mathrm{D}_{\mathrm{Sr}} * \mathrm{C}_{\mathrm{L}}^{\mathrm{Ca}}\right)-1\right) * 1000
\end{aligned}
$$

The error of the approximation of $\Delta^{88 / 86} \mathrm{Sr}_{\mathrm{DBL}}$ by using total strontium instead of ${ }^{86} \mathrm{Sr}$ concentrations can be calculated analogous to Eq. (A6) with $\mathrm{R}_{\mathrm{fl}}^{88 / 86}=0.119$. Again the calculated isotope offset underestimates the true DBL isotope effect. For $\alpha_{\mathrm{DBL}}=1.0002(0.2 \%)$ the error amounts to $0.02 \%$.

\section{Sensitivities to different control parameters}

Sensitivities of the isotope fractionation effects to the different parameters differ for $\mathrm{Ca}$ and $\mathrm{Sr}$. We calculated the response to doubling of BT, $\mathrm{V}, \mathrm{C}^{\mathrm{Ca}}, \mathrm{C}^{\mathrm{Sr}}, \mathrm{D}_{\mathrm{Ca}}, \mathrm{D}_{\mathrm{Sr}}, \mathrm{K}_{\mathrm{d}}, \Delta^{\mathrm{Ca}}{ }_{\text {cryst }}, \Delta^{\mathrm{Ca}}{ }_{\text {diff, }}, \Delta^{\mathrm{Sr}}{ }_{\text {rryst }}$, and $\Delta^{\mathrm{Sr}}{ }_{\text {diff, }}$, where $\Delta_{\text {cryst }}=\left(\alpha_{\mathrm{x}}-1\right) * 1000$, and $\Delta_{\text {diff }}=\left(\alpha_{\mathrm{d}}-1\right) * 1000$. The effects on $\Delta^{44 / 40} \mathrm{Ca}_{\mathrm{DBL}}$ and $\Delta^{88 / 86} \mathrm{Sr}_{\mathrm{DBL}}$ are shown in Table A1.

While $\mathrm{Ca}$ isotope effects change almost linearly, Sr isotopes show a non-linear behaviour at high $\mathrm{BT}^{*} \mathrm{~V}$ values, when $\mathrm{C}_{\mathrm{L}}^{\mathrm{Ca}}$ becomes small compared to $\mathrm{C}^{\mathrm{Ca}}$. This strongly increases the $\mathrm{Sr} / \mathrm{Ca}$ ratio near the crystal surface and therefore increases the uptake of Sr into the calcite crystal. The nonlinear behaviour of the $\mathrm{Sr}$ isotope fractionation effect is conspicuous in its response to doubling of $\mathrm{D}_{\mathrm{Ca}}$ and $\mathrm{K}_{\mathrm{d}}$ (Table A1).

The $\mathrm{Ca}$ isotope effects depend on the bulk solution calcium concentration $\left(\mathrm{C}^{\mathrm{Ca}}\right)$. In contrast, the isotope effect for $\mathrm{Sr}$ is independent of the bulk $\mathrm{Sr}$ concentration $\left(\mathrm{C}^{\mathrm{Sr}}\right)$, but is closely linked to the bulk Ca concentration $\left(\mathrm{C}^{\mathrm{Ca}}{ }_{0}\right)$.

The effect of isotope fractionation during diffusion is outweighed by the effect of selective uptake of light isotopes during crystal growth. The DBL is enriched in light isotopes as long as $\Delta_{\text {cryst }}<\Delta_{\text {diff. }}$. The isotope effect of the DBL, $\Delta_{\mathrm{DBL}}$, becomes zero when $\Delta_{\text {cryst }}=\Delta_{\text {diff. }}$ Only when $\Delta_{\text {cryst }}>\Delta_{\text {diff }}$ the DBL will get enriched in light isotopes.

For both isotope systems the crystal growth rate (V) and the thickness of the boundary layer (BT) are major controlling factors. While the growth rate was measured in our precipitation experiments, we did not measure BT. This introduces the most significant uncertainty to the quantification of the DBL effects. 
Table A1: Sensitivities of DBL isotope effects on doubling of system parameters

\begin{tabular}{|l|l|l|l|}
\hline Parameter & Standard value & \multicolumn{1}{|c|}{$\begin{array}{c}\text { Doubling parameter changes } \Delta_{\text {DBL }} \text { by } \\
\Delta^{44 / 40} \mathbf{C a}_{\text {DBL }}\end{array}$} \\
\hline $\mathrm{BT}$ & $0.1 \mathrm{~mm}$ & 2 -fold & about 2 -fold \\
\hline $\mathrm{V}$ & $10^{-9} \mathrm{~cm} / \mathrm{s}$ & 2 -fold & about 2 -fold \\
\hline $\mathrm{C}^{\mathrm{Ca}}{ }_{0}$ & $10.3 \mathrm{mmol} / \mathrm{L}$ & 0.5 -fold & about 0.5 -fold \\
\hline $\mathrm{C}^{\mathrm{Sr}}{ }_{0}$ & $0.09 \mathrm{mmol} / \mathrm{L}$ & no change & no change \\
\hline $\mathrm{D}_{\mathrm{Ca}}$ & $7 * 10^{-6} \mathrm{~cm}^{2} / \mathrm{s}$ & 0.5 -fold & 1 -fold to 0.5 -fold \\
\hline $\mathrm{D}_{\mathrm{Sr}}$ & $7 * 10^{-6} \mathrm{~cm}^{2} / \mathrm{s}$ & no change & 0.5 -fold \\
\hline$\Delta^{\mathrm{Ca}}{ }_{\text {cryst }}$ & $-1.50 \% 0$ & 2.4 -fold & no change \\
\hline$\Delta^{\mathrm{Ca}}{ }_{\text {diff }}$ & $-0.43 \% 0$ & 0.6 -fold & no change \\
\hline$\Delta^{\mathrm{Sr}}{ }_{\text {cryst }}$ & $-0.30 \% 0$ & no change & 2.5-fold \\
\hline$\Delta^{\mathrm{Sr}}{ }_{\text {diff }}$ & $-0.10 \% 0$ & no change & 0.5 -fold \\
\hline $\mathrm{K}_{\mathrm{d}}$ & 0.11 & no change & 2-fold to 1.1-fold \\
\hline
\end{tabular}

\section{Limits for the DBL thickness (BT)}

For a given crystal growth rate the thickness of the boundary layer is limited by the concentrations of the $\mathrm{Ca}^{2+}$ and $\mathrm{CO}_{3}{ }^{2-}$ ions at the liquid-crystal interface. The interface solution must be oversaturated with respect to calcite $\left(\Omega_{\mathrm{cc}}>1\right)$, otherwise the crystal stops growing. We use Eq. (A2) to calculate the concentrations of the two ions for a given bulk solution chemistry and a given crystal growth rate. With that we can estimate a maximum thickness of the boundary layer that still allows diffusion to maintain calcite oversaturation at the liquid-crystal interface.

The calculations were carried out for a seawater-like fluid composition, i.e. $\mathrm{C}^{\mathrm{Ca}}{ }_{0}=10.3 \mathrm{mmol} / \mathrm{L}$ and $\mathrm{C}^{\mathrm{CO} 3}{ }_{0}=0.26 \mathrm{mmol} / \mathrm{L}$. The calcite solubility constant $\mathrm{K}_{\mathrm{cc}}=0.43 \mathrm{mM}^{2}$ for the determination of $\Omega_{\mathrm{cc}}$ was calculated for normal salinity and a temperature of $25^{\circ} \mathrm{C}$ (Zeebe \& Wolf-Gladrow 2001). We use $\mathrm{C}^{\mathrm{Ca}}{ }_{\mathrm{x}}=27.1 \mathrm{mmol} / \mathrm{cm}^{3}$ and $\mathrm{C}^{\mathrm{CO} 3}{ }_{\mathrm{x}}=27.1 \mathrm{mmol} / \mathrm{cm}^{3}$. We assume that the boundary layer thickness is similar for $\mathrm{Ca}^{2+}, \mathrm{CO}_{3}{ }^{2-}$, and $\mathrm{HCO}_{3}{ }^{-}$. The boundary layer thickness in a stirred solution is controlled by turbulences in the fluid and therefore has a constant thickness for all ions. For crystals smaller than the smallest turbulences the boundary layer thickness is largely defined by the V/D ratio and the crystal radius, $\mathrm{r}_{\mathrm{x}}$ (Watson and Müller, 2009). As $\mathrm{V}$ and $\mathrm{r}_{\mathrm{x}}$ are identical for $\mathrm{Ca}^{2+}, \mathrm{CO}_{3}{ }^{2-}$, and $\mathrm{HCO}_{3}{ }^{-}$ ions and $\mathrm{D}$ in aqueous solution differs only slightly between these ions $\left(\mathrm{D}_{\mathrm{Ca}}=7 * 10^{-6} \mathrm{~cm}^{2} / \mathrm{s}, \mathrm{D}_{\mathrm{CO} 3}=\right.$ $8 * 10^{-6} \mathrm{~cm}^{2} / \mathrm{s}, \mathrm{D}_{\mathrm{HCO} 3}=1 * 10^{-5} \mathrm{~cm}^{2} / \mathrm{s}$, Wolf-Gladrow and Riebesell, 1997), our assumption is a reasonable approximation. 
As not only $\mathrm{CO}_{3}{ }^{2-}$ ions are involved in the calcite growth we used the diffusion-reaction model described in Zeebe \& Wolf-Gladrow (2001) to calculate speciation and diffusion of all carbonate system components. The latter approach slightly relaxes the constraints on BT given by considering $\mathrm{CO}_{3}{ }^{2-}$ concentration only. This is because diffusion and reaction of $\mathrm{OH}^{-}, \mathrm{CO}_{2}$, and $\mathrm{HCO}_{3}{ }^{-}$contribute additional $\mathrm{CO}_{3}{ }^{2-}$ ions for calcite formation.

Considering only $\mathrm{CO}_{3}{ }^{2-}$ with a concentration typical for warm surface seawater we calculate a maximum possible DBL reduction of $\mathrm{C}^{\mathrm{Ca}}$ to $97 \%$ of $\mathrm{C}^{\mathrm{Ca}}$ (with $\mathrm{C}^{\mathrm{Ca}}{ }_{0}=10.3 \mathrm{mM}$ ). Considering the whole carbonate system $\left(\Sigma \mathrm{CO}_{2}\right)$ the maximum possible $\mathrm{C}_{\mathrm{L}}^{\mathrm{Ca}}$ reduction only slightly changes to $95 \%$ of $\mathrm{C}^{\mathrm{Ca}}{ }_{0}$. With the standard fractionations and diffusion constants listed in Table A1 the resulting maximum $\Delta^{44 / 40} \mathrm{Ca}_{\mathrm{DBL}}$ and $\Delta^{88 / 86} \mathrm{Sr}_{\mathrm{DBL}}$ values are $0.05 \%$ and $0.001 \%$, respectively. The corresponding BT values and maximum precipitation rates are shown in Table A2.

Table A2: Maximum DBL thickness and growth rate for calcite precipitation limited by $\mathrm{CO}_{3}{ }^{2-} / \Sigma \mathrm{CO}_{2}$ availability and calcite saturation state in seawater

\begin{tabular}{|c|c|c|}
\hline \multirow{2}{*}{$\begin{array}{c}\text { BT } \\
(\mathbf{m m})\end{array}$} & \multicolumn{2}{|c|}{$\begin{array}{c}\text { maximum } \mathbf{l o g}(\mathbf{R}) \\
\left(\boldsymbol{\mu m o l} / \mathbf{m}^{2} / \mathbf{s}\right)\end{array}$} \\
\cline { 2 - 3 } & $\begin{array}{c}\mathbf{C O}_{3}{ }^{2-} \\
\text { limited }\end{array}$ & $\begin{array}{c}\boldsymbol{\Sigma} \mathbf{C O}_{2} \\
\text { limited }\end{array}$ \\
\hline 0.02 & 4.50 & 4.78 \\
\hline 0.05 & 4.10 & 4.38 \\
\hline 0.10 & 3.80 & 4.08 \\
\hline 0.15 & 3.62 & 3.90 \\
\hline 0.20 & 3.50 & 3.78 \\
\hline 0.50 & 3.10 & 3.40 \\
\hline 1.00 & 2.80 & 3.08 \\
\hline 2.00 & 2.50 & 2.78 \\
\hline
\end{tabular}




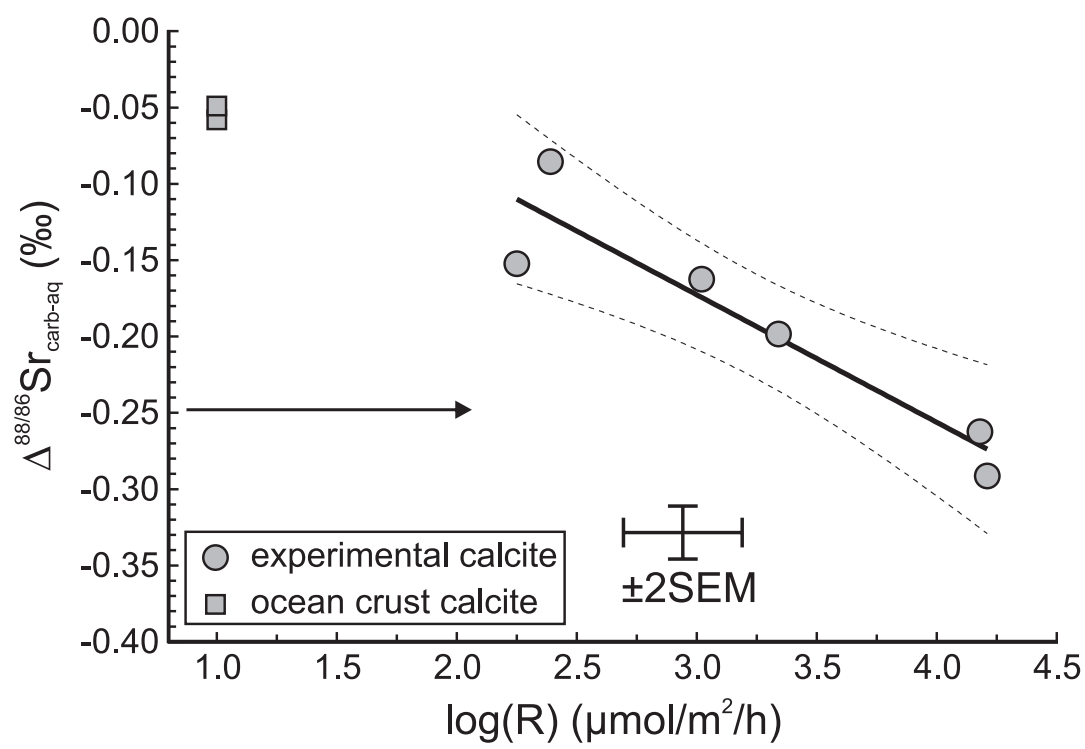

Fig. 1 


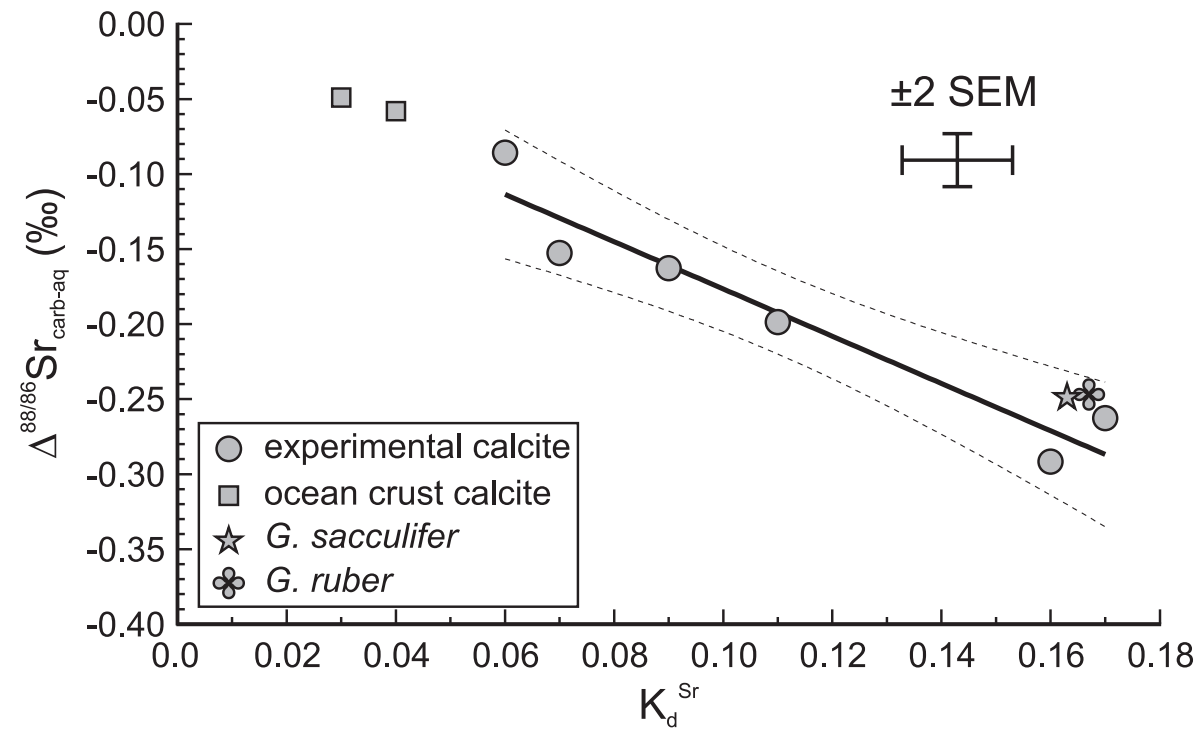

Fig. 2 


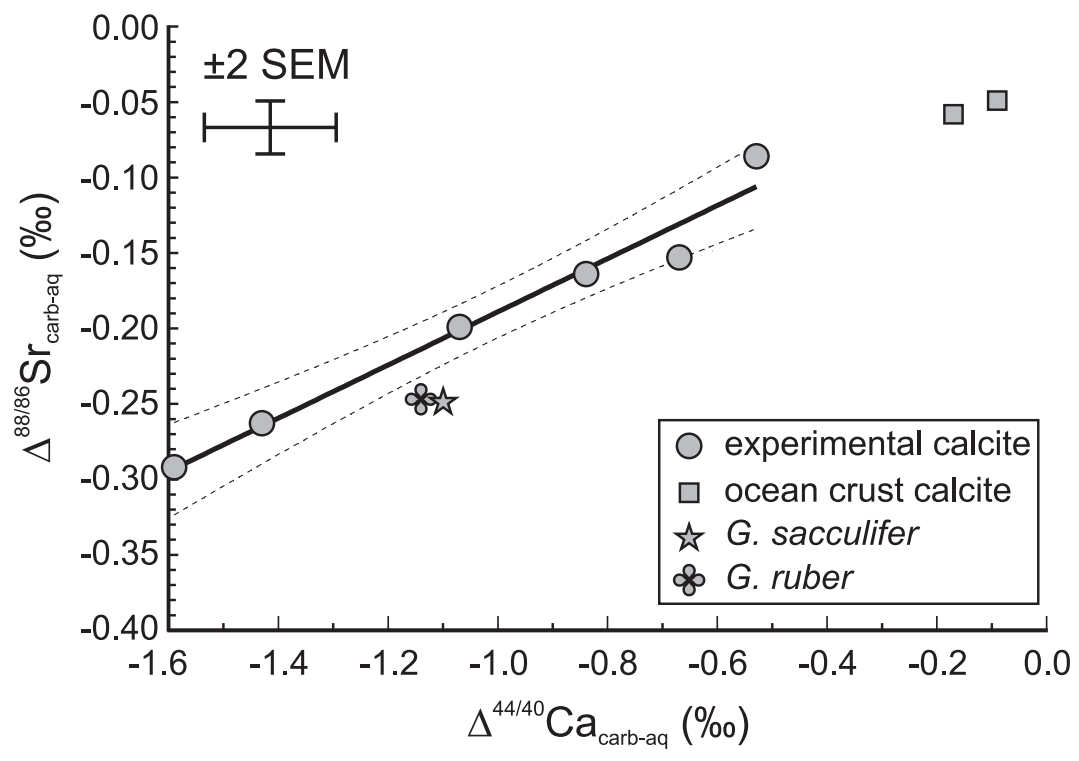

Fig. 3 


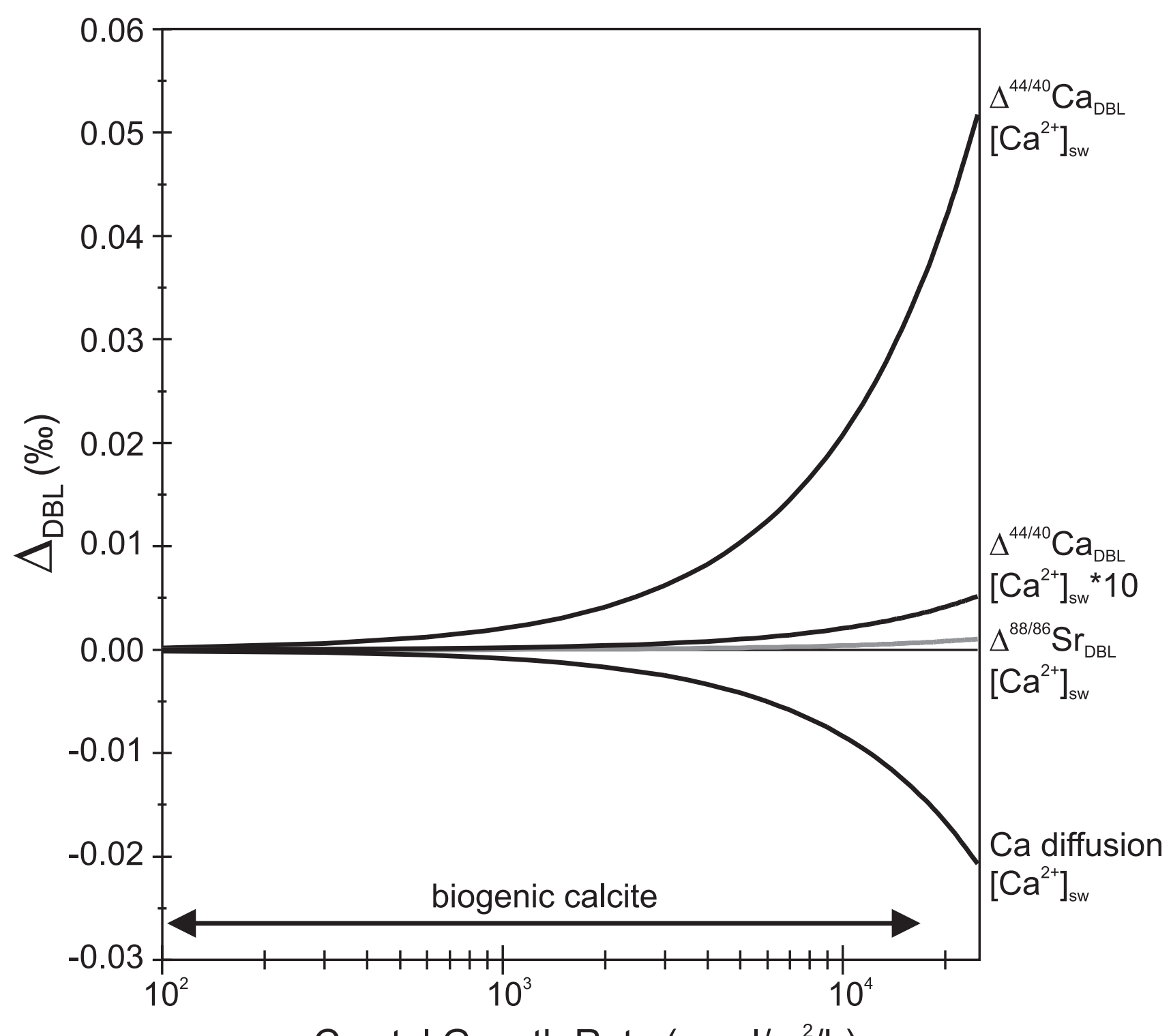

Crystal Growth Rate $\left(\mu \mathrm{mol} / \mathrm{m}^{2} / \mathrm{h}\right)$

Fig. 4 


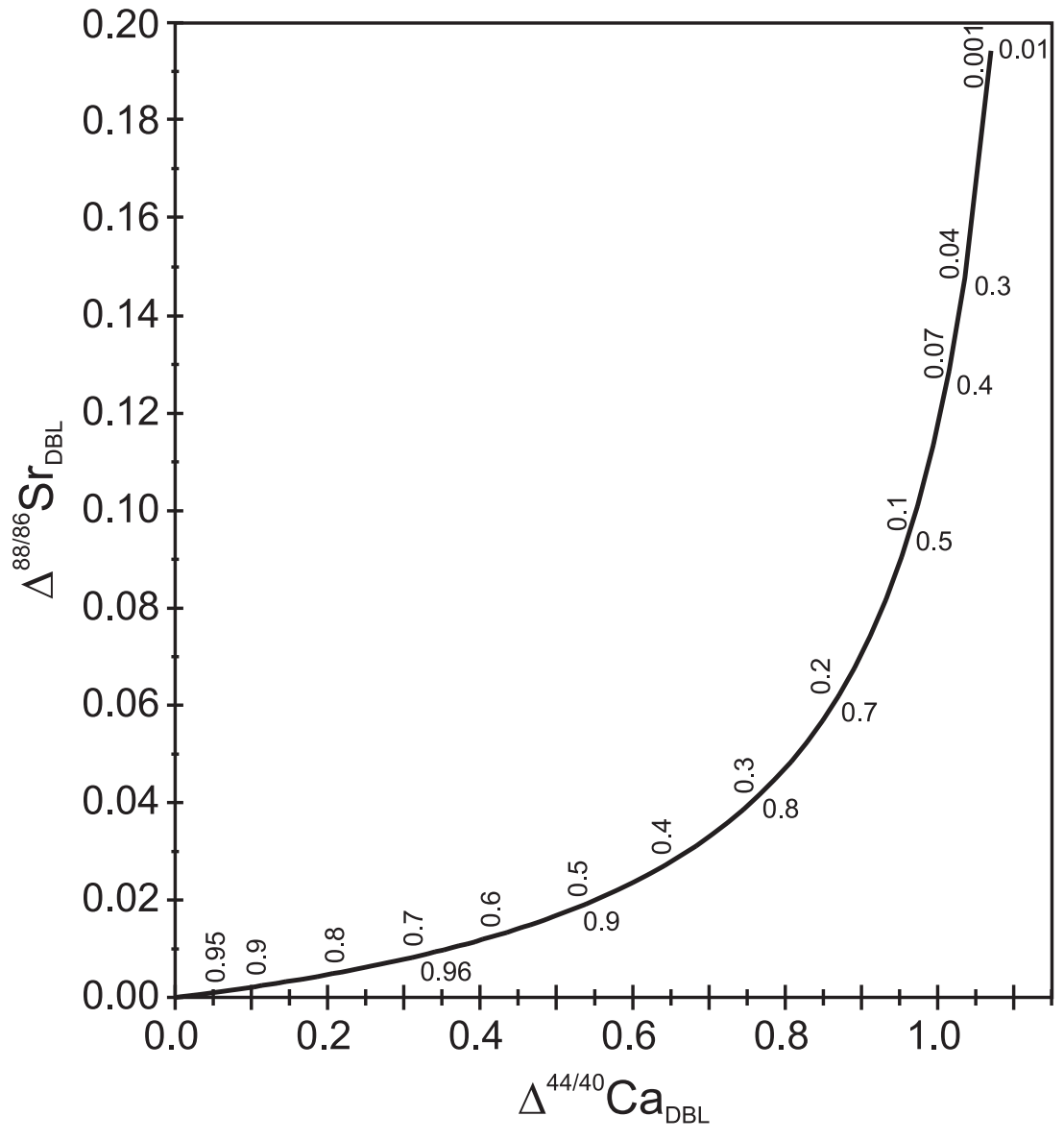

Fig. 5 